\title{
Femtomolar Zn(II) Affinity in a Protein Ligand Designed to Model Thiolate-Rich Metalloprotein Active Sites
}

\author{
$\underline{\text { Supplementary Material }}$
}

\author{
Amy K. Petros ${ }^{\dagger}$, Amit R. Reddi ${ }^{\dagger}$, Michelle L. Kennedy ${ }^{\dagger}$, \\ Alison G. Hyslop ${ }^{\S}$, Brian R. Gibney ${ }^{\dagger}$ \\ ${ }^{\dagger}$ Department of Chemistry, Columbia University, 3000 Broadway, \\ MC 3121, New York, NY 10027 \\ § Department of Chemistry, St. John's University, 8000 Utopia Parkway, \\ Queens, NY 11439 \\ e-mail:brg@chem.columbia.edu
}




\section{Materials and Methods}

Reagents: Trifluoroacetic acid, ethanedithiol, 1-hydroxybenzotriazole, diethyl ether, acetic anhydride, diisopropylethylamine (DIEA), piperidine were obtained from the Sigma-Aldrich Chemical Company. Natural Fmoc-protected amino acids were obtained from Bachem. HBTU, O-(1H-benzotriazole-1-yl)- $N, N, N^{\prime}, N^{\prime}$-tetramethyluronium hexafluorophosphate, was purchased from Qbiogene. All other chemicals and solvents were reagent grade and used without further purification.

Peptide Ligand Synthesis: The peptide ligand IGA was synthesized on a continuous flow Applied Biosystems Pioneeer solid phase synthesizer using the Fmoc/t ${ }^{\mathrm{Bu}}$ protection strategy with PAL-PEG-PS resin $(0.20 \mathrm{mmol} / \mathrm{g}$ loading $)$ at 0.2 mmole scale. Single extended coupling cycles (60 min.) with HBTU/DIEA activation chemistry were employed for all amino acids. The side chain protecting groups used are, as follows: Lys ( $\left.{ }^{\mathrm{t}} \mathrm{Boc}\right)$; Glu $\left(\mathrm{O}^{\mathrm{t}} \mathrm{Bu}\right)$; Cys (Trt). Each peptide was cleaved from the resin and simultaneously deprotected using 90:8:2 (v/v/v) trifluoroacetic acid : ethanedithiol : water for 2 hours. Crude peptides were triturated with cold ether, dissolved in water $(0.1 \% \mathrm{v} / \mathrm{v}$ TFA $)$, lyophilized, and purified to homogeneity by reversed phase $\mathrm{C}_{18}$ HPLC using aqueous-acetonitrile gradients containing $0.1 \%(\mathrm{v} / \mathrm{v})$ TFA. After lyophilization, the identities of the resulting peptide ligands were confirmed with matrix assisted laser desorption ionization mass spectrometry (MALDI-MS).

UV-visible spectroscopy: UV-visible spectra were recorded on either a Varian Cary 100 or a Bio50 spectrophotometer using quartz cells of $1.0 \mathrm{~cm}$ pathlength. $\mathrm{pH}$ titration experiments monitored in the visible wavelength region were performed manually using an anaerobic $1.0 \mathrm{~cm}$ pathlength cuvette fitted with a $\mathrm{pH}$ electrode. Peptide 
concentrations were determined spectrophotometrically using $\varepsilon_{280}$ of $5600 \mathrm{M}^{-1} \mathrm{~cm}^{-1}$ for Trp.

Fluorescence Spectroscopy: Excitation and emission fluorescence spectra were recorded on a Cary Eclipse fluorimeter using rectangular quartz cells of $1.0 \mathrm{~cm}$ pathlength. Excitation and emission slit widths of $5 \mathrm{~nm}$ were employed. $\mathrm{pH}$ titrations were performed using an automated titrator attached to an AVIV 215 circular dichroism spectropolarimeter with a total fluorescence attachment. The excitation wavelength was $280 \mathrm{~nm}$ and the total fluorescence emission was collected after a $310 \mathrm{~nm}$ high band pass filter. The sample was maintained at $25^{\circ} \mathrm{C}$ by a thermoelectric module with a ThermoNeslab refrigerated recirculating water bath as a heat sink. Peptide concentrations were between 10-30 $\mu \mathrm{M}$ as determined spectrophotometrically using $\varepsilon_{280}=5600 \mathrm{M}^{-1}$ $\mathrm{cm}^{-1}$ for Trp.

Determination of Metal Ion Affinities by Direct Titration: Aqueous stock solutions of each metal were added in microliter aliquots to freshly prepared IGA peptide solutions in aqueous buffers under strictly anaerobic conditions in cuvettes of $1 \mathrm{~cm}$ or 10 $\mathrm{cm}$ pathlength. Samples were allowed to equilibrate for $3 \mathrm{~min}$. before measurement of their UV-vis or fluorescence spectra. The conditional metal-ligand dissociation constants, conditional $\mathrm{K}_{\mathrm{d}}$ values, were obtained from fitting the spectroscopic data plotted against the $\left[\right.$ Metal $\left._{\text {total }}\right] /\left[\right.$ Peptide $\left._{\text {total }}\right]$ according to the following equations for a $1: 1$ binding equilibrium measured by absorbance and fluorescence.

$$
\begin{aligned}
& \text { IGA }+\mathrm{M}(\mathrm{II}) \cdot \mathrm{xH}_{2} \mathrm{O} \rightleftharpoons \mathrm{M}(\mathrm{II})-\mathbf{I G A}+\mathrm{xH}_{2} \mathrm{O} \\
& \mathrm{K}_{\mathrm{d}} \mathrm{M}(\mathrm{II})=\left[\mathrm{M}(\mathrm{II}) \cdot \mathrm{xH}_{2} \mathrm{O}\right][\mathbf{I G A}] /[\mathrm{M}(\mathrm{II})-\mathbf{I G A}]
\end{aligned}
$$

For absorbance measurements, the data are fit to the following: 
$\mathrm{Abs}=\mathrm{Abs}_{0}+\varepsilon_{\mathrm{B}} *(0.5)\left(\mathrm{x} *\left[\mathrm{~L}_{\mathrm{T}}\right]+\mathrm{K}_{\mathrm{d}}+\left[\mathrm{L}_{\mathrm{T}}\right]-\operatorname{sqrt}\left\{\left(\mathrm{x} *\left[\mathrm{~L}_{\mathrm{T}}\right]+\mathrm{K}_{\mathrm{d}}+\left[\mathrm{L}_{\mathrm{T}}\right]\right)^{2}-4 \mathrm{x} *\left[\mathrm{~L}_{\mathrm{T}}\right]^{2}\right\}+\right.$

$\varepsilon_{\mathrm{F}} *\left(\mathrm{x} *\left[\mathrm{~L}_{\mathrm{T}}\right]\right)-\varepsilon_{\mathrm{F}} *(0.5)\left(\mathrm{x} *\left[\mathrm{~L}_{\mathrm{T}}\right]+\mathrm{K}_{\mathrm{d}}+\left[\mathrm{L}_{\mathrm{T}}\right]\right)-\operatorname{sqrt}\left\{\left(\mathrm{x} *\left[\mathrm{~L}_{\mathrm{T}}\right]+\mathrm{K}_{\mathrm{d}}+\left[\mathrm{L}_{\mathrm{T}}\right]\right)^{2}-4 \mathrm{x} *\left[\mathrm{~L}_{\mathrm{T}}\right]^{2}\right\}$

Where Abs is the total absorbance, $\mathrm{Abs}_{0}$ is the initial absorbance of the IGA ligand prior to addition of metal, $\varepsilon_{\mathrm{B}}$ and $\varepsilon_{\mathrm{F}}$ are the molar extinction coefficients of bound and free metal, respectively, $\mathrm{x}$ is the ratio of total metal to total ligand $\left(\left[\mathrm{M}_{\mathrm{T}}\right] /\left[\mathrm{L}_{\mathrm{T}}\right]\right)$, or equivalents of metal added, $\left[\mathrm{L}_{\mathrm{T}}\right]$ is the total concentration of the IGA ligand, and $\mathrm{K}_{\mathrm{d}}$ is the conditional dissociation constant.

For fluorescence, the equation used to fit the data is, as follows:

$$
\begin{aligned}
\mathrm{F}_{\mathrm{T}}=\mathrm{F}_{\mathrm{L}}+\left(\mathrm{F}_{\mathrm{ML}}-\mathrm{F}_{\mathrm{L}} / 2 *\left[\mathrm{~L}_{\mathrm{T}}\right]\right) *\left(\left(\left(\left[\mathrm{~L}_{\mathrm{T}}\right]^{*} \mathrm{x}\right)+\left[\mathrm{L}_{\mathrm{T}}\right]+\mathrm{K}_{\mathrm{d}}\right)\right. \\
\left.-\operatorname{sqrt}\left(\left(\left[\mathrm{L}_{\mathrm{T}}\right]^{*} \mathrm{x}+\left[\mathrm{L}_{\mathrm{T}}\right]+\mathrm{K}_{\mathrm{d}}\right)^{2}-\left(4 * \mathrm{x}^{*}\left[\mathrm{~L}_{\mathrm{T}}\right]^{2}\right)\right)\right)
\end{aligned}
$$

Where $\mathrm{F}_{\mathrm{T}}$ is total fluorescence, $\mathrm{F}_{\mathrm{L}}$ is the fluorescence of the IGA ligand prior to metal binding, $\mathrm{F}_{\mathrm{ML}}$ is the fluorescence of the $\mathrm{Zn}(\mathrm{II})-\mathrm{IGA}$ complex, $\mathrm{x}$ is the ratio of total metal to total ligand $\left(\left[\mathrm{M}_{\mathrm{T}}\right] /\left[\mathrm{L}_{\mathrm{T}}\right]\right)$, or equivalents of metal added, $\left[\mathrm{L}_{\mathrm{T}}\right]$ is the total concentration of the IGA ligand, and $\mathrm{K}_{\mathrm{d}}$ is the conditional dissociation constant.

Determination of Metal Ion Affinities by Metal Ion Competition Studies: The displacement of a metal, $M_{A}$, bound to IGA with another metal of higher affinity, $M_{B}$, was followed by either UV-visible or fluorescence spectroscopy. The change in signal due to displacement of $\mathrm{M}_{\mathrm{A}}$ by $\mathrm{M}_{\mathrm{B}}$ in IGA was fit to an equilibrium competition constant, $\mathrm{K}_{\text {comp }}{ }^{\mathrm{A} / \mathrm{B}}$, expressed as an equilibrium dissociation constant. The measured competition constant coupled with the dissociation constant for one of the metals was used to determine the dissociation constant for the other metal according to the relationship 
$\mathrm{K}_{\text {comp }} \mathrm{A} / \mathrm{B}=\mathrm{K}_{\mathrm{d}} \mathrm{MA} / \mathrm{K}_{\mathrm{d}} \mathrm{MB}$. For the displacement of $\mathrm{Fe}(\mathrm{II})$ bound to IGA by $\mathrm{Co}(\mathrm{II})$, as monitored by absorption spectroscopy (Figure 5C) the following equations apply:

$$
\begin{aligned}
& \mathrm{Fe}(\mathrm{II})-\mathbf{I G A}+\mathrm{Co}(\mathrm{II}) \cdot \mathrm{xH}_{2} \mathrm{O} \rightleftharpoons \mathrm{Co}(\mathrm{II})-\mathbf{I G A}+\mathrm{Fe}(\mathrm{II}) \cdot \mathrm{xH}_{2} \mathrm{O} \\
& \mathrm{K}_{\mathrm{d}} \mathrm{Fe}(\mathrm{II})=\left[\mathrm{Fe}(\mathrm{II}) \cdot \mathrm{xH}_{2} \mathrm{O}\right][\mathbf{I G A}] /[\mathrm{Fe}(\mathrm{II})-\mathbf{I G A}] \\
& \mathrm{K}_{\mathrm{d}} \mathrm{Co}(\mathrm{II})=\left[\mathrm{Co}(\mathrm{II}) \cdot \mathrm{xH}_{2} \mathrm{O}\right][\mathbf{I G A}] /[\mathrm{Co}(\mathrm{II}) \mathbf{I G A}] \\
& \mathrm{K}_{\text {comp }} \mathrm{Fe} / \mathrm{Co}=\left[\mathrm{Fe}(\mathrm{II}) \cdot \mathrm{xH}_{2} \mathrm{O}\right][\mathrm{Co}(\mathrm{II})-\mathrm{IGA}] /\left[\mathrm{Co}(\mathrm{II}) \cdot \mathrm{xH}_{2} \mathrm{O}\right][\mathrm{Fe}(\mathrm{II})-\mathbf{I G A}] \\
& \mathrm{K}_{\text {comp }}{ }^{\mathrm{Fe} / \mathrm{Co}}=\mathrm{K}_{\mathrm{d}} \mathrm{Fe}(\mathrm{II}) / \mathrm{K}_{\mathrm{d}} \mathrm{Co} \text { (II) } \\
& \text { Abs }=\operatorname{Abs}_{0}+\left(\varepsilon_{M_{A}} L^{*} L_{T}\right)+\left(\varepsilon_{M_{B} L}-\varepsilon_{M_{A} L}\right) *\left[-B+\operatorname{sqrt}\left\{B^{2}+\right.\right. \\
& \left.\left.\left(4 * \mathrm{~A} *\left(\mathrm{~K}_{\text {comp }}{ }^{\mathrm{A} / \mathrm{B}}\right) * \mathrm{x}^{*} \mathrm{~L}_{\mathrm{T}}{ }^{2}\right)\right\}\right] / 2 \mathrm{~A} \\
& \mathrm{~A}=1-\mathrm{K}_{\text {comp }}{ }^{\mathrm{A} / \mathrm{B}} \\
& \mathrm{B}=\mathrm{M}_{\mathrm{AT}}-\mathrm{L}_{\mathrm{T}}+\left(\mathrm{K}_{\mathrm{comp}}{ }^{\mathrm{A} / \mathrm{B}}\right)\left(\mathrm{L}_{\mathrm{T}}\right)+\left(\mathrm{K}_{\mathrm{comp}}{ }^{\mathrm{A} / \mathrm{B}}\right)\left(\mathrm{x}^{*} \mathrm{~L}_{\mathrm{T}}\right)
\end{aligned}
$$

Where Abs is the total absorbance, $\mathrm{Abs}_{0}$ is the initial absorbance of the IGA ligand bound to metal A prior to addition of metal $\mathrm{B}, \varepsilon_{\mathrm{M}_{\mathrm{A}} \mathrm{L}}$ and $\varepsilon_{\mathrm{M}_{\mathrm{B}} \mathrm{L}}$ are the molar extinction coefficients of IGA bound to metal A and metal B, respectively, $\left[\mathrm{L}_{\mathrm{T}}\right]$ is the total concentration of the IGA ligand, $\mathrm{x}$ is the ratio of total metal $\mathrm{B}$ to total ligand $\left(\left[\mathrm{M}_{\mathrm{BT}}\right] /\right.$ $\left[\mathrm{L}_{\mathrm{T}}\right]$ ), or equivalents of metal B added, $\left[\mathrm{L}_{\mathrm{T}}\right]$ is the total concentration of the IGA ligand, $\left[\mathrm{M}_{\mathrm{AT}}\right]$ is the total concentration of metal $\mathrm{A}$, and $\mathrm{K}_{\mathrm{comp}} \mathrm{A} / \mathrm{B}$ is the conditional competition constant.

For the displacement of Co(II) bound to IGA by Zn(II), as monitored by fluorescence spectroscopy (Figure 7C) the following equations apply 


$$
\begin{aligned}
& \mathrm{Co}(\mathrm{II})-\mathbf{I G A}+\mathrm{Zn}(\mathrm{II}) \cdot \mathrm{xH}_{2} \mathrm{O} \rightleftharpoons \mathrm{Zn}(\mathrm{II})-\mathrm{IGA}+\mathrm{Co}(\mathrm{II}) \cdot \mathrm{xH}_{2} \mathrm{O} \\
& \mathrm{K}_{\mathrm{d}} \mathrm{Co}(\mathrm{II})=\left[\mathrm{Co}(\mathrm{II}) \cdot \mathrm{xH}_{2} \mathrm{O}\right][\mathbf{I G A}] /[\mathrm{Co}(\mathrm{II})-\mathbf{I G A}] \\
& \mathrm{K}_{\mathrm{d}} \mathrm{Zn}(\mathrm{II})=\left[\mathrm{Zn}(\mathrm{II}) \cdot \mathrm{xH}_{2} \mathrm{O}\right][\mathbf{I G A}] /[\mathrm{Zn}(\mathrm{II}) \mathbf{I G A}] \\
& \mathrm{K}_{\text {comp }} \mathrm{Co} / \mathrm{Zn}=\left[\mathrm{Co}(\mathrm{II}) \cdot \mathrm{xH}_{2} \mathrm{O}\right][\mathrm{Zn}(\mathrm{II})-\mathbf{I G A}] /\left[\mathrm{Zn}(\mathrm{II}) \cdot \mathrm{xH}_{2} \mathrm{O}\right][\mathrm{Co}(\mathrm{II})-\mathbf{I G A}] \\
& \mathrm{K}_{\mathrm{comp}} \mathrm{Co} / \mathrm{Zn}=\mathrm{K}_{\mathrm{d}} \mathrm{Co}(\mathrm{II}) / \mathrm{K}_{\mathrm{d}} \mathrm{Zn}(\mathrm{II}) \\
& \mathrm{F}_{\mathrm{T}}=\mathrm{F}_{\mathrm{o}}+\left\{\left\{-\mathrm{B}+\left\{\mathrm{B}^{2}+\left(4 * \mathrm{~A} * \mathrm{~K}_{\mathrm{comp}} \mathrm{A} / \mathrm{B} * \mathrm{x}^{*} \mathrm{~L}_{\mathrm{T}}^{2}\right)\right\}^{.5}\right\} / 2 \mathrm{~A} * \mathrm{~L}_{\mathrm{T}}\right\} *\left(\mathrm{~F}_{\lim }-\mathrm{F}_{\mathrm{o}}\right) \\
& \mathrm{A}=1-\mathrm{K}_{\mathrm{comp}}^{\mathrm{A} / \mathrm{B}} \\
& \mathrm{B}=\mathrm{M}_{\mathrm{AT}}-\mathrm{L}_{\mathrm{T}}+\left(\mathrm{K}_{\mathrm{comp}}{ }^{\mathrm{A} / \mathrm{B}}\right)\left(\mathrm{L}_{\mathrm{T}}\right)+\left(\mathrm{K}_{\mathrm{comp}}{ }^{\mathrm{A} / \mathrm{B}}\right)\left(\mathrm{x}^{*} \mathrm{~L}_{\mathrm{T}}\right)
\end{aligned}
$$

Where $\mathrm{F}_{\mathrm{T}}$ is the total fluorescence, $\mathrm{F}_{\mathrm{O}}$ is the initial fluorescence of the IGA ligand bound to metal A prior to addition of metal $\mathrm{B}, \mathrm{F}_{\mathrm{lim}}$ is the fluorescence of the IGA ligand $100 \%$ bound to metal $\mathrm{B},\left[\mathrm{L}_{\mathrm{T}}\right]$ is the total concentration of the IGA ligand, $\mathrm{x}$ is the ratio of total metal $\mathrm{B}$ to total ligand $\left(\left[\mathrm{M}_{\mathrm{BT}}\right] /\left[\mathrm{L}_{\mathrm{T}}\right]\right)$, or equivalents of metal $\mathrm{B}$ added, $\left[\mathrm{L}_{\mathrm{T}}\right]$ is the total concentration of the IGA ligand, $\left[\mathrm{M}_{\mathrm{AT}}\right]$ is the total concentration of metal A, and $\mathrm{K}_{\text {comp }} \mathrm{A} / \mathrm{B}$ is the conditional competition constant.

Determination of Zn(II) Affinities by EDTA Competition. For $\mathrm{pH}$ values above 7, conditional equilibrium dissociation constant determination for the $\mathrm{Zn}$ (II)-IGA complex necessitated the use of EDTA (ethylenediaminetetraacetic acid) competition. To buffered aqueous solutions (either 20mM HEPES, .1M KCl or 20mM Potassium Phosphate, .1M KCl) of 10-15 $\mu \mathrm{M}$ IGA and between .5-5 eq of EDTA, at pH's between 7 and $8, \mathrm{Zn}(\mathrm{II})$ was added in microliter aliquots under strictly anaerobic conditions. The increase in fluorescence at $357 \mathrm{~nm}$ upon the addition of $\mathrm{Zn}(\mathrm{II})$ was fit to a competition equilibrium binding model based on equation S.17. 


$$
\begin{aligned}
& \mathrm{Zn}(\mathrm{II})-\mathrm{EDTA}+\text { IGA } \rightleftharpoons \mathrm{Zn}(\mathrm{II})-\text { IGA }+ \text { EDTA } \\
& \mathrm{K}_{\mathrm{comp}}=\mathrm{K}_{\mathrm{d}} \mathrm{Zn}(\mathrm{II})-\mathrm{EDTA} / \mathrm{K}_{\mathrm{d}} \mathrm{Zn}(\mathrm{II})-\mathbf{I G A}
\end{aligned}
$$

$\mathrm{F}_{\mathrm{T}}=\mathrm{F}_{\mathrm{o}}+\left(\left(\mathrm{F}_{\text {lim }}-\mathrm{F}_{\mathrm{o}}\right) /\left(\left(2-2 * \mathrm{~K}_{\mathrm{comp}}\right) *\left[\mathrm{~L}_{\mathrm{T}}\right]\right)\right) *\left(\left(\mathrm{x}^{*}\left[\mathrm{~L}_{\mathrm{T}}\right]-\left[\mathrm{EDTA}_{\mathrm{T}}\right]-\mathrm{K}_{\mathrm{comp}}{ }^{*} \mathrm{x}^{*}\left[\mathrm{~L}_{\mathrm{T}}\right]-\right.\right.$

$\left.\mathrm{K}_{\mathrm{comp}} *\left[\mathrm{~L}_{\mathrm{T}}\right]\right)+\operatorname{sqrt}\left(\left(\mathrm{x} *\left[\mathrm{~L}_{\mathrm{T}}\right]-\left[\mathrm{EDTA}_{\mathrm{T}}\right]-\mathrm{K}_{\mathrm{comp}} * \mathrm{x}^{*}\left[\mathrm{~L}_{\mathrm{T}}\right]-\mathrm{K}_{\mathrm{comp}} *\left[\mathrm{~L}_{\mathrm{T}}\right]\right)^{2+4 *}\left(1-\mathrm{K}_{\mathrm{comp}}\right) *\left[\mathrm{~L}_{\mathrm{T}}\right]^{2}\right.$

$\left.\left.*^{*} \mathrm{~K}_{\text {comp }}\right)\right)$

Where $\mathrm{F}_{\mathrm{T}}$ is total fluorescence, $\mathrm{F}_{\mathrm{o}}$ is the fluorescence of the IGA ligand prior to $\mathrm{Zn}(\mathrm{II})$ binding, $\mathrm{F}_{\mathrm{lim}}$ is the fluorescence of the IGA ligand $100 \%$ bound to $\mathrm{Zn}(\mathrm{II})$, $\mathrm{x}$ is the ratio of total metal to total ligand $\left(\left[\mathrm{M}_{\mathrm{T}}\right] /\left[\mathrm{L}_{\mathrm{T}}\right]\right)$, or equivalents of metal added, $\left[\mathrm{L}_{\mathrm{T}}\right]$ is the total concentration of the IGA ligand, $\left[\mathrm{EDTA}_{\mathrm{T}}\right]$ is the total concentration of EDTA, and $\mathrm{K}_{\text {comp }}$ is the conditional competition constant.

The $\mathrm{K}_{\text {comp }}$ value, coupled with the conditional equilibrium dissociation constant value of

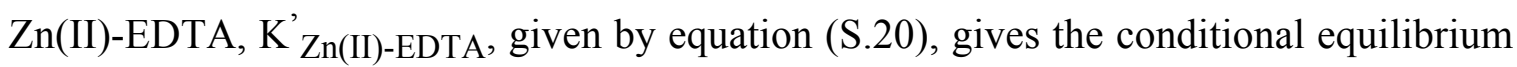
dissociation constant value for $\mathrm{Zn}(\mathrm{II})$-IGA.

$$
\begin{aligned}
& \mathrm{K}_{\mathrm{Zn}(\mathrm{II})-\mathrm{EDTA}}=\mathrm{K}_{\mathrm{Zn}(\mathrm{II})-\mathrm{EDTA}} * \alpha_{\mathrm{L}} \\
& \alpha_{\mathrm{L}}=\mathrm{K}_{1} \mathrm{~K}_{2} \mathrm{~K}_{3} \mathrm{~K}_{4} \mathrm{~K}_{5} \mathrm{~K}_{6} /\left(\mathrm{K}_{1} \mathrm{~K}_{2} \mathrm{~K}_{3} \mathrm{~K}_{4} \mathrm{~K}_{5} \mathrm{~K}_{6}+\mathrm{K}_{1} \mathrm{~K}_{2} \mathrm{~K}_{3} \mathrm{~K}_{4} \mathrm{~K}_{5}\left[\mathrm{H}^{+}\right]+\mathrm{K}_{1} \mathrm{~K}_{2} \mathrm{~K}_{3} \mathrm{~K}_{4}\left[\mathrm{H}^{+}\right]^{2}\right. \\
& \left.\quad+\mathrm{K}_{1} \mathrm{~K}_{2} \mathrm{~K}_{3}\left[\mathrm{H}^{+}\right]^{3}+\mathrm{K}_{1} \mathrm{~K}_{2}\left[\mathrm{H}^{+}\right]^{4}+\mathrm{K}_{1}\left[\mathrm{H}^{+}\right]^{5}\left[\mathrm{H}^{+}\right]^{6}\right)
\end{aligned}
$$


Where $\alpha_{L}$ is the mole fraction of fully deprotonated EDTA, $K_{\mathrm{Zn}(\mathrm{II}) \text {-EDTA }}\left(=10^{16.5}\right)$ is the formation constant of fully deprotonated EDTA for $\mathrm{Zn}(\mathrm{II}),{ }^{1}$ and $\mathrm{K}_{(1-6)}$ are the proton dissociation constants of EDTA ${ }^{1} ; \mathrm{K}_{1}=1, \mathrm{~K}_{2}=.031, \mathrm{~K}_{3}=.01, \mathrm{~K}_{4}=.0022, \mathrm{~K}_{5}=6.92^{*} 10^{-}$ $7, \mathrm{~K}_{6}=5.75^{*} 10^{-11}$

Proton Competition Studies: Under anaerobic conditions, a dilute solution of $\mathrm{HCl}$ in water was added in microliter aliquots to solutions of each metal complex of IGA prepared in a cuvette fitted with a $\mathrm{pH}$ electrode. The absorbance or fluorescence data as a function of $\mathrm{pH}$ results from the following step-wise protonation equilibria.

$$
\begin{aligned}
& \mathrm{pK}_{\mathrm{a}} \mathrm{MLH}_{4} \quad \mathrm{M}(\mathrm{II})-\mathbf{I G A}-4 \mathrm{H}^{+} \rightleftharpoons \mathrm{M}(\mathrm{II})-\mathbf{I G A}-3 \mathrm{H}^{+}+\mathrm{H}^{+} \\
& \mathrm{pK}_{\mathrm{a}} \mathrm{MLH}_{3} \quad \mathrm{M}(\mathrm{II})-\mathbf{I G A}-3 \mathrm{H}^{+} \rightleftharpoons \mathrm{M}(\mathrm{II})-\mathbf{I G A}-2 \mathrm{H}^{+}+\mathrm{H}^{+} \\
& \mathrm{pK}_{\mathrm{a}} \mathrm{MLH}_{2} \quad \mathrm{M}(\mathrm{II})-\mathbf{I G A}-2 \mathrm{H}^{+} \rightleftharpoons \mathrm{M}(\mathrm{II})-\mathbf{I G A}-\mathrm{H}^{+}+\mathrm{H}^{+} \\
& \mathrm{pK}_{\mathrm{a}} \mathrm{MLH}_{1} \quad \mathrm{M}(\mathrm{II})-\mathbf{I G A}-\mathrm{H}^{+} \rightleftharpoons \mathrm{M}(\mathrm{II})-\mathbf{I G A}+\mathrm{H}^{+}
\end{aligned}
$$

Thus, there are five possible protonation states, $\mathrm{MLH}_{\mathrm{x}}$ where $\mathrm{x}=0-4$, of the metal-ligand complex. The observed spectroscopic signal $\left(\mathrm{S}_{\mathrm{T}}\right)$ is the sum of the intrinsic signals of each $\mathrm{MLH}_{\mathrm{x}}$ species, $\mathrm{S}_{\mathrm{MLH}_{\mathrm{X}}} \mathrm{x}=0$ - 4, weighted by its mole fraction in solution, $-\mathrm{MLH}_{\mathrm{X}}$ (the fraction of $\left[\mathrm{MLH}_{\mathrm{x}}\right]$ present over all forms of metal ligand species, $\Sigma \mathrm{MLH}_{\mathrm{X}}$ ).

$$
\begin{aligned}
& \mathrm{S}_{\mathrm{T}}=\left(\mathrm{S}_{\mathrm{ML}{ }^{*} \_\mathrm{ML}}\right)+\left(\mathrm{S}_{\mathrm{MLH}{ }^{*} \_\mathrm{MLH}}\right)+\left(\mathrm{S}_{\mathrm{MLH}_{2}}{ }^{*} \_\mathrm{MLH}_{2}\right)+\left(\mathrm{S}_{\mathrm{MLH}_{3}}{ }^{*} \mathrm{MLH}_{3}\right)+ \\
& \left(\mathrm{S}_{\mathrm{MLH}_{4}}{ }^{*}-\mathrm{MLH}_{4}\right)
\end{aligned}
$$


The mole fractions of each $\mathrm{MLH}_{\mathrm{X}}$ species, ${ }_{-} \mathrm{MLH}_{\mathrm{X}}$, are given as function of solution $\mathrm{pH}$, their respective $\mathrm{pK}_{\mathrm{a}} \mathrm{MLH}_{\mathrm{x}}\left(\mathrm{x}=0\right.$ - 4) values and the values of the $\mathrm{pK}_{\mathrm{a}} \mathrm{LH}_{\mathrm{x}}(\mathrm{x}=0$ - 4) value of the IGA ligand, $\mathrm{LH}_{4}$.

$$
\begin{aligned}
& -\mathrm{MLH}_{4}=10(-4 * \mathrm{pH}) / \Sigma \mathrm{MLH}_{\mathrm{x}} \\
& { }_{-} \mathrm{MLH}_{3}=10\left(-3 * \mathrm{pH}-\mathrm{pK}_{\mathrm{a}} \mathrm{MLH}_{4}\right) / \Sigma \mathrm{MLH}_{\mathrm{x}} \\
& { }_{-} \mathrm{MLH}_{2}=10\left(-2 * \mathrm{pH}-\mathrm{pK}_{\mathrm{a}} \mathrm{MLH}_{4}-\mathrm{pK}_{\mathrm{a}} \mathrm{MLH}_{3}\right) / \Sigma \mathrm{MLH}_{\mathrm{x}}
\end{aligned}
$$

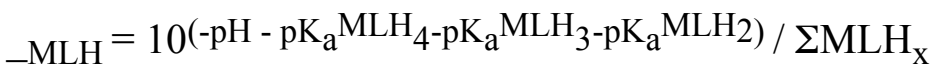

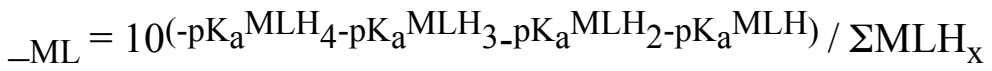

$$
\begin{aligned}
& \Sigma \mathrm{MLH}_{\mathrm{x}}=[\mathrm{ML}]+\left[\mathrm{MLH}_{1}\right]+\left[\mathrm{MLH}_{2}\right]+\left[\mathrm{MLH}_{3}\right]+\left[\mathrm{MLH}_{4}\right]
\end{aligned}
$$

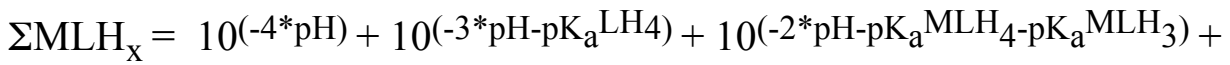

$$
\begin{aligned}
& 10\left(-\mathrm{pH}_{\mathrm{pK}} \mathrm{MLH}_{4}-\mathrm{pK}_{\mathrm{a}} \mathrm{MLH}_{3}-\mathrm{pK}_{\mathrm{a}} \mathrm{MLH}_{2}\right)+10\left(-\mathrm{pK}_{\mathrm{a}} \mathrm{MLH}_{4}-\mathrm{pK}_{\mathrm{a}} \mathrm{MLH}_{3}-\mathrm{pK}_{\mathrm{a}} \mathrm{MLH}_{2-} \mathrm{pK}_{\mathrm{a}} \mathrm{MLH}\right)
\end{aligned}
$$

The simplest model that adequately fit the data sets for Fe(II), Co(II) and Zn(II) complexes of IGA is one in which there are two acid dissociation constants, one represents a one proton event at $\mathrm{pK}_{\mathrm{a} 1}$ eff and the other a cooperative three proton event at $\mathrm{pK}_{\mathrm{a} 2}{ }^{\text {eff. }}$.

$$
\begin{array}{ll}
\mathrm{pK}_{\mathrm{a} 1}{ }^{\text {eff }} & \mathrm{M}(\mathrm{II})-\mathbf{I G A}-\mathrm{H}^{+} \rightleftharpoons \mathrm{M}(\mathrm{II})-\mathbf{I G A}+\mathrm{H}^{+} \\
\mathrm{pK}_{\mathrm{a} 2}{ }^{\mathrm{eff}} & \mathrm{M}(\mathrm{II})-\mathbf{I G A}-4 \mathrm{H}^{+} \rightleftharpoons \mathrm{M}(\mathrm{II})-\mathbf{I G A}-\mathrm{H}^{+}+3 \mathrm{H}^{+}
\end{array}
$$

Thus, the general equation above reduces to the following,

$$
\begin{aligned}
& \mathrm{S}_{\mathrm{T}}=\left(\mathrm{S}_{\mathrm{ML}}{ }^{*} \_\mathrm{ML}\right)+\left(\mathrm{S}_{\mathrm{MLH}}{ }^{*} \_\mathrm{MLH}\right)+\left(\mathrm{S}_{\mathrm{MLH} 4} *{ }_{-} \mathrm{MLH}_{4}\right) \\
& { }_{-} \mathrm{MLH}_{4}=10(-4 * \mathrm{pH}) / \Sigma \mathrm{MLH}_{\mathrm{x}} \text { coop } \\
& { }_{-} \mathrm{MLH}=10\left(-\mathrm{pH}-3 * \mathrm{pK}_{\mathrm{a} 2}{ }^{\mathrm{eff}}\right) / \Sigma \mathrm{MLH}_{\mathrm{x}}{ }^{\text {coop }} \\
& { }_{-} \mathrm{ML}=10\left(-\mathrm{pK}_{\mathrm{a} 2} \text { eff } * 3-\mathrm{pK}_{\mathrm{a} 1} \text { eff }\right) / \Sigma \mathrm{MLH}_{\mathrm{x}} \text { coop }
\end{aligned}
$$




$$
\begin{aligned}
& \Sigma \mathrm{MLH}_{\mathrm{X}} \mathrm{coop}=[\mathrm{ML}]+\left[\mathrm{MLH}_{1}\right]+\left[\mathrm{MLH}_{4}\right]
\end{aligned}
$$

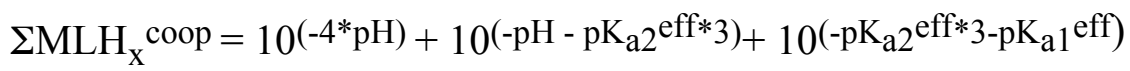

Determination of Metal Ion Affinities as a Function of pH: Due to the expected $\left[\mathrm{H}^{+}\right]^{4}$ dependence of the IGA ligand's conditional $\mathrm{K}_{\mathrm{d}}$ value, $\mathrm{K}_{\mathrm{d}}$ 's were measured at a series of $\mathrm{pH}$ values. The $\mathrm{K}_{\mathrm{d}}$ value at each $\mathrm{pH}$ was determined as above using either UV-visible or fluorescence spectroscopies. The resulting plots of $-\log \mathrm{K}_{\mathrm{d}}$ versus measured $\mathrm{pH}$ are fit to the following equation:

$\log \mathrm{K}_{\mathrm{f}}{ }^{\prime}=\mathrm{K}_{\mathrm{f}}{ }^{\prime} \mathrm{MLH}_{4}+\mathrm{K}_{\mathrm{f}}{ }^{\prime} \mathrm{MLH}+\mathrm{K}_{\mathrm{f}}{ }^{\prime} \mathrm{ML}$

Where $\mathrm{K}_{\mathrm{f}}$, the observed conditional formation constant at any given solution $\mathrm{pH}$, is a sum of the conditional formation constants of the various protonated metal-ligand

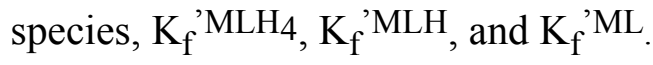

$$
\begin{aligned}
& \log \mathrm{K}_{\mathrm{f}}{ }^{\prime}=\left(\mathrm{LH}_{4} * \mathrm{~K}_{\mathrm{f}} \mathrm{MLH}_{4} /{ }_{-\mathrm{MLH}}\right)+\left(\__{\mathrm{LH}} * \mathrm{~K}_{\mathrm{f}} \mathrm{MLH} /{ }_{\mathrm{MLH}}\right)+\left(\__{\mathrm{L}} * \mathrm{~K}_{\mathrm{f}} \mathrm{ML} /{ }_{\mathrm{ML}}\right) \\
& \log \mathrm{K}_{\mathrm{f}}^{\prime}=\log \left\{\left(\left(\mathrm { LH } _ { 4 } * \left(10\left(-\mathrm{pK}_{\mathrm{a}} \mathrm{LH}_{+} \mathrm{pK}_{\mathrm{a}} \mathrm{MLH}\right) *\left(\left(10\left(-\mathrm{pK}_{\mathrm{a}} \mathrm{LH}_{4} * 3+\mathrm{pK}_{\mathrm{a}} \mathrm{MLH}_{4} * 3\right)\right) * \mathrm{~K}_{\mathrm{f}} \mathrm{ML}\right) /\right.\right.\right.\right. \\
& \left.\left.{ }_{-} \mathrm{MLH}_{4}\right)+\left(\left(\mathrm{LH}^{*}\left(10\left(-\mathrm{pK}_{\mathrm{a}} \mathrm{LH}+\mathrm{pK}_{\mathrm{a}} \mathrm{MLH}\right)\right) * \mathrm{~K}_{\mathrm{f}}^{\mathrm{ML}}\right) /{ }_{\mathrm{MLH}}\right)+\left(\mathrm{L}^{*} \mathrm{~K}_{\mathrm{f}} \mathrm{ML} /{ }_{\mathrm{ML}}\right)\right\} \\
& \text { where }{ }_{-} \mathrm{LH}_{4}=10^{(-4 * \mathrm{pH})} /{ }_{-} \text {Lcoop } \\
& { }_{-} \mathrm{LH}=10\left(-\mathrm{pH}-3 * \mathrm{pK}_{\mathrm{a}} \mathrm{LH}\right){ }_{\text {_L Lcoop }} \\
& -\mathrm{L}=10\left(-\mathrm{pK}_{\mathrm{a}} \mathrm{LH}_{4} * 3-\mathrm{pK}_{\mathrm{a}} \mathrm{LH}\right) /{ }_{-} \mathrm{Lcoop}
\end{aligned}
$$

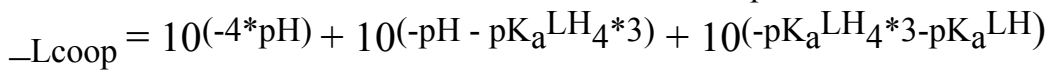

$$
\begin{aligned}
& -\mathrm{MLH}_{4}=10^{(-4 * \mathrm{pH})} /{ }_{-\mathrm{MLcoop}} \\
& -\mathrm{MLH}=10\left(-\mathrm{pH}-3 * \mathrm{pK}_{\mathrm{a}} \mathrm{MLH}_{4}\right) / \_ \text {MLcoop } \\
& -\mathrm{ML}=10\left(-\mathrm{pK}_{\mathrm{a}} \mathrm{MLH}_{4} * 3-\mathrm{pK}_{\mathrm{a}} \mathrm{MLH}\right) /{ }_{-\mathrm{MLcoop}} \\
& -{ }_{-M L c o o p}=10^{(-4 * p H)}+10\left(-\mathrm{pH}-\mathrm{pK}_{\mathrm{a}} \mathrm{MLH}_{4} * 3\right)+10\left(-\mathrm{pK}_{\mathrm{a}} \mathrm{MLH}_{4} * 3-\mathrm{pK}_{\mathrm{a}} \mathrm{MLH}\right)
\end{aligned}
$$


Where $\mathrm{pK}_{\mathrm{a}} \mathrm{LH}_{\mathrm{x}}$ is the $\mathrm{pK}_{\mathrm{a}}$ value of the IGA ligand (assumed to be 8.3 or that of free cysteine), $\mathrm{pK}_{\mathrm{a}} \mathrm{MLH}_{\mathrm{x}}$ values are the effective $\mathrm{pK}_{\mathrm{a}}$ values of the individual metal-ligand species as derived from proton competition studies $\left(\mathrm{pK}_{\mathrm{a} 1}\right.$ eff and $\mathrm{pK}_{\mathrm{a} 2}$ eff $), \mathrm{K}_{\mathrm{f}}^{\mathrm{ML}}\left(=\beta_{110}\right)$ is the formation constant of the ML complex from metal and deprotonated ligand ( $\left.\mathrm{L}^{4-}\right)$, and $\mathrm{K}_{\mathrm{f}}^{\prime}$ is the conditional formation constant of the metal-ligand species at a particular $\mathrm{pH}$ value. The value of $\beta_{110}\left(=\mathrm{K}_{\mathrm{f}}^{\mathrm{ML}}\right)$ is related to the overall formation constant, $\beta_{114}$, which describes the formation of $\mathrm{MLH}_{4}$ from one $\mathrm{M}(\mathrm{II})$, one IGA, and $4 \mathrm{H}^{+}$, by a factor of $\left(1 / \mathrm{K}_{\mathrm{a} 1}\right.$ eff $) *\left(1 / \mathrm{K}_{\mathrm{a} 2} \text { eff }\right)^{3}$, the acid association constants of the metal bound cysteine ligands.

$$
\begin{aligned}
& \beta_{110}=\mathrm{K}_{\mathrm{f}}^{\mathrm{ML}} \mathrm{M}(\mathrm{II})+\text { IGA } \rightleftharpoons \mathrm{M}(\mathrm{II}) \text {-IGA } \\
& \beta_{114} \quad \mathrm{M}(\mathrm{II})+\text { IGA }+4 \mathrm{H}^{+} \rightleftharpoons \mathrm{M}(\mathrm{II})-\mathbf{I G A}-4 \mathrm{H}^{+} \\
& \beta_{114}=\beta_{110} *\left(1 / \mathrm{K}_{\mathrm{a} 1} \text { eff }\right) *\left(1 / \mathrm{K}_{\mathrm{a} 2} \text { eff }\right)^{3}
\end{aligned}
$$




\section{Derivations of Equilibrium Binding Models}

\section{pH Dependent Chemical Speciation of the Ferredoxin Maquettes}

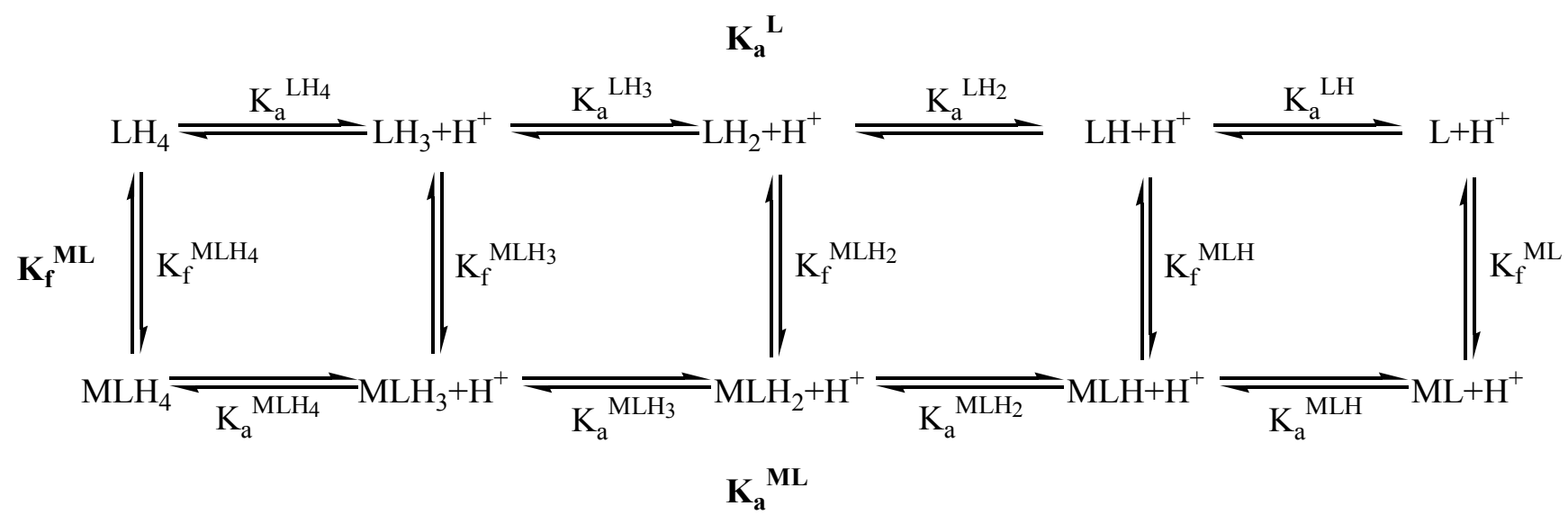

Figure 1: Stepwise formation, $\mathbf{K}_{\mathbf{f}} \mathbf{M L}$, and proton dissociation, $\mathbf{K}_{\mathbf{a}} \mathbf{L}$ and $\mathbf{K}_{\mathbf{a}} \mathbf{M L}$, constants relevant to the complex equilibria of metal substituted Ferredoxin Maquettes.

$$
\begin{aligned}
& \mathbf{K}_{\mathbf{a}}^{\mathbf{L}} \quad \mathrm{K}_{\mathrm{a}} \mathrm{LH}_{4}=\left[\mathrm{LH}_{3}\right]\left[\mathrm{H}^{+}\right] /\left[\mathrm{LH}_{4}\right] \\
& \mathrm{K}_{\mathrm{a}} \mathrm{LH}_{3}=\left[\mathrm{LH}_{2}\right]\left[\mathrm{H}^{+}\right] /\left[\mathrm{LH}_{3}\right] \\
& \mathrm{K}_{\mathrm{a}} \mathrm{LH}_{2}=[\mathrm{LH}]\left[\mathrm{H}^{+}\right] /\left[\mathrm{LH}_{2}\right] \\
& \mathrm{K}_{\mathrm{a}}^{\mathrm{LH}}=[\mathrm{L}]\left[\mathrm{H}^{+}\right] /[\mathrm{LH}] \\
& \mathbf{K}_{\mathbf{a}} \mathbf{M L} \quad \mathrm{K}_{\mathrm{a}} \mathrm{MLH}_{4}=\left[\mathrm{MLH}_{3}\right]\left[\mathrm{H}^{+}\right] /\left[\mathrm{MLH}_{4}\right] \\
& \mathrm{K}_{\mathrm{a}} \mathrm{MLH}_{3}=\left[\mathrm{MLH}_{2}\right]\left[\mathrm{H}^{+}\right] /\left[\mathrm{MLH}_{3}\right] \\
& \mathrm{K}_{\mathrm{a}} \mathrm{MLH}_{2}=[\mathrm{MLH}]\left[\mathrm{H}^{+}\right] /\left[\mathrm{MLH}_{2}\right] \\
& \mathrm{K}_{\mathrm{a}} \mathrm{MLH}=[\mathrm{ML}]\left[\mathrm{H}^{+}\right] /[\mathrm{MLH}] \\
& \mathbf{K}_{\mathbf{f}}^{\mathbf{M L}} \quad \mathrm{K}_{\mathrm{f}}^{\mathrm{MLH}_{4}}=\left[\mathrm{MLH}_{4}\right] /[\mathrm{M}]\left[\mathrm{LH}_{4}\right] \\
& \mathrm{K}_{\mathrm{f}} \mathrm{MLH}_{3}=\left[\mathrm{MLH}_{3}\right] /[\mathrm{M}]\left[\mathrm{LH}_{3}\right] \\
& \mathrm{K}_{\mathrm{f}} \mathrm{MLH}_{2}=\left[\mathrm{MLH}_{2}\right] /[\mathrm{M}]\left[\mathrm{LH}_{2}\right] \\
& \mathrm{K}_{\mathrm{f}} \mathrm{MLH}=[\mathrm{MLH}] /[\mathrm{M}][\mathrm{LH}] \\
& \mathrm{K}_{\mathrm{f}}^{\mathrm{ML}}=[\mathrm{ML}] /[\mathrm{M}][\mathrm{L}]
\end{aligned}
$$




\section{Modeling the $\mathbf{p H}$ Dependency of the Conditional Formation Constant, $\mathrm{K}_{\mathrm{f}} \mathrm{ML}$.}

The solution $\mathrm{pH}$ dictates the extent to which various protonated metal-ligand complexes, $\mathrm{ML}(\mathrm{H})_{\mathrm{x}}$ or M(II)-IGA-(H) , are able to form, i.e. ML, MLH, $\mathrm{MLH}_{2}$, $\mathrm{MLH}_{3}, \mathrm{MLH}_{4}$. If one wishes to determine an equilibrium binding constant for ML, two conditions must be satisfied; the experiment must be performed 1) at a $\mathrm{pH}$ where $\mathrm{ML}$ is the predominant species present, and 2) the ligand concentration must be on the order of the equilibrium dissociation constant, $\mathrm{K}_{\mathrm{d}}\left(=1 / \mathrm{K}_{\mathrm{f}}\right)$. In many cases, it is nearly impossible to meet "condition 2". For example, many biological macromolecules have nanomolar or tighter affinities for metal at a given $\mathrm{pH}$, as does IGA for $\mathrm{Zn}(\mathrm{II})$. However, it is often times very difficult to measure changes in experimental signal at such low concentrations. One method workers in the field employ is to perform equilibrium formation constant measurements at lower $\mathrm{pH}$ 's, where protons compete with the metal for ligand binding. This effectively lowers the ligand's affinity for metal, thereby allowing the researcher to perform experiments at higher, more reasonable ligand concentrations. However, this methodology violates "condition 1"; the formation constant measured at a lower $\mathrm{pH}$ is no longer the formation constant for ML, but rather any number of other protonated metal-ligand complexes in equilibrium, i.e. $\mathrm{MLH}, \mathrm{MLH}_{2}, \mathrm{MLH}_{3}, \mathrm{MLH}_{4}$. In order to obtain a true equilibrium formation constant for ML (when it's affinity for metal is too tight to be measured at a given $\mathrm{pH}$ ), one should generate a plot of the conditional formation constant as a function of $\mathrm{pH}$. Proper fitting of this plot will allow one to derive an equilibrium formation constant for ML. The following is a derivation of the function used to fit the $\mathrm{pH}$ dependence of the conditional formation constant of $\mathrm{Fe}(\mathrm{II}), \mathrm{Co}(\mathrm{II})$, and $\mathrm{Zn}$ (II) substituted IGA.

Over the relevant $\mathrm{pH}$ range (4-9), the $\mathrm{ML}(\mathrm{H})_{\mathrm{x}}$ species in solution are $\mathrm{ML}, \mathrm{MLH}$, $\mathrm{MLH}_{2}, \mathrm{MLH}_{3}$, and $\mathrm{MLH}_{4}$. Their formation constants are given by:

$$
\begin{aligned}
\mathrm{K}_{\mathrm{f}} \mathrm{MLH}_{4} & =\left[\mathrm{MLH}_{4}\right] /[\mathrm{M}]\left[\mathrm{LH}_{4}\right] \\
\mathrm{K}_{\mathrm{f}} \mathrm{MLH}_{3} & =\left[\mathrm{MLH}_{3}\right] /[\mathrm{M}]\left[\mathrm{LH}_{3}\right] \\
\mathrm{K}_{\mathrm{f}} \mathrm{MLH}_{2} & =\left[\mathrm{MLH}_{2}\right] /[\mathrm{M}]\left[\mathrm{LH}_{2}\right] \\
\mathrm{K}_{\mathrm{f}} \mathrm{MLH} & =[\mathrm{MLH}] /[\mathrm{M}][\mathrm{LH}] \\
\mathrm{K}_{\mathrm{f}} \mathrm{ML} & =[\mathrm{ML}] /[\mathrm{M}][\mathrm{L}]
\end{aligned}
$$

Because the formation of each of these species is $\mathrm{pH}$ dependent, one must define a set of conditional formation constants, $\mathbf{K}_{\mathbf{f}}$, that are functions of $\mathrm{pH}$. We do this by first defining $\mathbf{K}_{\mathbf{f}}{ }^{\text {in }}$ in terms of a quantity , which is defined to be the mole fraction of a particular species present in solution.

$$
\mathrm{K}_{\mathrm{f}}{ }^{\mathrm{MLH}} 4=\left(\left[\mathrm{MLH}_{4}\right] /{ }_{-} \mathrm{MLH}_{4}\right) /\left([\mathrm{M}]\left[\mathrm{LH}_{4}\right] /{ }_{-} \mathrm{LH}_{4}\right)
$$




$$
\begin{aligned}
& \mathrm{K}_{\mathrm{f}}{ }^{{ }^{M} H_{3}}=\left(\left[\mathrm{MLH}_{3}\right] /{ }_{-} \mathrm{MLH}_{3}\right) /\left([\mathrm{M}]\left[\mathrm{LH}_{3}\right] /{ }_{-} \mathrm{LH}_{3}\right) \\
& \mathrm{K}_{\mathrm{f}}{ }^{{ }^{\mathrm{MLH}} 2}=\left(\left[\mathrm{MLH}_{2}\right] /{ }_{-} \mathrm{MLH}_{2}\right) /\left([\mathrm{M}]\left[\mathrm{LH}_{2}\right] /{ }_{-} \mathrm{LH}_{2}\right) \\
& \mathrm{K}_{\mathrm{f}}{ }^{\prime} \mathrm{MLH}=\left([\mathrm{MLH}] /{ }_{\mathrm{MLH}}\right) /\left([\mathrm{M}][\mathrm{LH}] /{ }_{-} \mathrm{LH}\right) \\
& \mathrm{K}_{\mathrm{f}}{ }^{\mathrm{ML}}=\left([\mathrm{ML}] /{ }_{\mathrm{ML}}\right) /\left([\mathrm{M}][\mathrm{L}] /_{-} \mathrm{L}\right) \\
& \mathrm{L}_{\mathrm{T}}=\left[\mathrm{LH}_{4}\right]+\left[\mathrm{LH}_{3}\right]+\left[\mathrm{LH}_{2}\right]+[\mathrm{LH}]+[\mathrm{L}]
\end{aligned}
$$

where $\mathrm{L}_{\mathrm{T}}$ is the mass balance for all forms of free ligand, $\mathrm{L}$.

$\mathrm{ML}_{\mathrm{T}}=\left[\mathrm{MLH}_{4}\right]+\left[\mathrm{MLH}_{3}\right]+\left[\mathrm{MLH}_{2}\right]+[\mathrm{MLH}]+[\mathrm{ML}]$

where $\mathrm{ML}_{\mathrm{T}}$ is the mass balance for all forms of bound metal (metal-ligand complex), ML.

$$
\begin{aligned}
-\mathrm{MLH}_{4} & =\left[\mathrm{MLH}_{4}\right] / \mathrm{ML}_{\mathrm{T}} \\
-\mathrm{MLH}_{3} & =\left[\mathrm{MLH}_{3}\right] / \mathrm{ML}_{\mathrm{T}} \\
-\mathrm{MLH}_{2} & =\left[\mathrm{MLH}_{2}\right] / \mathrm{ML}_{\mathrm{T}} \\
-\mathrm{MLH} & =[\mathrm{MLH}] / \mathrm{ML}_{\mathrm{T}} \\
-\mathrm{ML} & =[\mathrm{ML}] / \mathrm{ML}_{\mathrm{T}} \\
-\mathrm{LH}_{4} & =\left[\mathrm{LH}_{4}\right] / \mathrm{L}_{\mathrm{T}} \\
-\mathrm{LH}_{3} & =\left[\mathrm{LH}_{3}\right] / \mathrm{L}_{\mathrm{T}} \\
-\mathrm{LH}_{2} & =\left[\mathrm{LH}_{2}\right] / \mathrm{L}_{\mathrm{T}} \\
-\mathrm{LH} & =[\mathrm{LH}] / \mathrm{L}_{\mathrm{T}} \\
-\mathrm{L} & =[\mathrm{L}] / \mathrm{L}_{\mathrm{T}}
\end{aligned}
$$

As $\rightarrow 1, \mathbf{K}_{\mathbf{f}}{ }^{\prime} \rightarrow \mathbf{K}_{\mathbf{f}}$; (the conditional formation constant, $\mathbf{K}_{\mathbf{f}}$ ', approaches the true formation constant, $\mathbf{K}_{\mathbf{f}}$ ) Consider Eq. I.10. When the fractions of $\mathrm{L}$ and ML in solution, _L and _ML, are 1, the true equilibrium formation constant (I.5) is obtained. As soon as _L and _ML drop below 1, the conditional formation constant, $\mathrm{K}_{\mathrm{f}}{ }^{\prime} \mathrm{ML}$, becomes a function of $\mathrm{L}_{\mathrm{T}}$ and $\mathrm{ML}_{\mathrm{T}}$. The only way the fraction of a given species, _, can change, is if the $\mathrm{pH}$ changes. Thus, _of a given species can be put in terms of $\mathrm{pH}$. However, before this is done, let us first relate the conditional formation constant, $\mathbf{K}_{\mathbf{f}}$, to the true, unconditional formation constant $\mathbf{K}_{\mathbf{f}}$. After all, the eventual goal is to obtain $\mathbf{K}_{\mathbf{f}}{ }^{\mathbf{M L}}$ from a plot of $\mathbf{K}_{\mathbf{f}}$ ' vs. $\mathrm{pH}$.

To relate $\mathbf{K}_{\mathbf{f}}$ ' to $\mathbf{K}_{\mathbf{f}}$, plug equations (I.1-I.5) into (I.6-I.10). This gives

$$
\begin{aligned}
& \mathrm{K}_{\mathrm{f}}{ }^{{ }^{\mathrm{MLH}}} 4=\left(\mathrm{LH}_{4}{ }^{*} \mathrm{~K}_{\mathrm{f}} \mathrm{MLH}_{4}\right) /{ }_{-} \mathrm{MLH}_{4} \\
& \mathrm{~K}_{\mathrm{f}}{ }^{{ }^{M} \mathrm{MLH}_{3}}=\left(\mathrm{LLH}_{3} * \mathrm{~K}_{\mathrm{f}}{ }^{\mathrm{MLH}} 3\right)^{\prime} / \mathrm{MLH}_{3} \\
& \mathrm{~K}_{\mathrm{f}}{ }^{{ }^{\mathrm{MLH}} 2}=\left(\mathrm{LH}_{2}{ }^{*} \mathrm{~K}_{\mathrm{f}}{ }^{\mathrm{MLH}_{2}}\right) /{ }_{-} \mathrm{MLH}_{2}
\end{aligned}
$$




$$
\begin{aligned}
& \mathrm{K}_{\mathrm{f}}{ }^{\mathrm{MLH}}=\left(\mathrm{LH}^{*} \mathrm{~K}_{\mathrm{f}}{ }^{\mathrm{MLH}}\right) /{ }_{-\mathrm{MLH}} \\
& \mathrm{K}_{\mathrm{f}}{ }^{\prime} \mathrm{ML}=\left(\mathrm{L}^{*} \mathrm{~K}_{\mathrm{f}}{ }^{\mathrm{ML}}\right) /{ }_{-\mathrm{ML}}
\end{aligned}
$$

In order to put in terms of $\mathrm{pH}$, let us first generate a series of expressions that define $L_{T}$ and $\bar{M} L_{T}$ in terms of all forms of free ligand, $L$, and metal-ligand complex, ML, respectively. We do this by relating the equilibria highlighted in the thermodynamic scheme in Figure 1 to the free ligand and metal-ligand complex mass balances, I.11 and I.12.

$$
\begin{aligned}
& \mathrm{L}_{\mathrm{T}}=[\mathrm{L}] *\left\{\left(\left[\mathrm{H}^{+}\right]^{4} / \mathrm{K}_{\mathrm{a}} \mathrm{LH}_{4} * \mathrm{~K}_{\mathrm{a}} \mathrm{LH}_{3} * \mathrm{~K}_{\mathrm{a}} \mathrm{LH}_{2} * \mathrm{~K}_{\mathrm{a}}^{\mathrm{LH}}\right)+\left(\left[\mathrm{H}^{+}\right]^{3} / \mathrm{K}_{\mathrm{a}} \mathrm{LH}_{3} * \mathrm{~K}_{\mathrm{a}} \mathrm{LH}_{2} * \mathrm{~K}_{\mathrm{a}}{ }^{\mathrm{LH}}\right)\right. \\
& \left.+\left(\left[\mathrm{H}^{+}\right]^{2} / \mathrm{K}_{\mathrm{a}} \mathrm{LH}_{2} * \mathrm{~K}_{\mathrm{a}}^{\mathrm{LH}}\right)+\left(\left[\mathrm{H}^{+}\right] / \mathrm{K}_{\mathrm{a}}^{\mathrm{LH}}\right)+1\right\}
\end{aligned}
$$

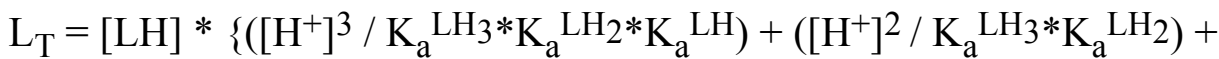

$$
\begin{aligned}
& \left.\left(\left[\mathrm{H}^{+}\right] / \mathrm{K}_{\mathrm{a}}^{\mathrm{LH}} 3\right)+\left(\mathrm{K}_{\mathrm{a}}^{\mathrm{LH}} 4 /\left[\mathrm{H}^{+}\right]\right)+1\right\} \\
& \mathrm{L}_{\mathrm{T}}=\left[\mathrm{LH}_{2}\right] *\left\{\left(\left[\mathrm{H}^{+}\right]^{2} / \mathrm{K}_{\mathrm{a}} \mathrm{LH}_{3} * \mathrm{~K}_{\mathrm{a}} \mathrm{LH}_{4}\right)+\left(\left[\mathrm{H}^{+}\right] / \mathrm{K}_{\mathrm{a}} \mathrm{LH}_{3}\right)+\left(\mathrm{K}_{\mathrm{a}} \mathrm{LH}_{2} /\left[\mathrm{H}^{+}\right]\right)+\right.
\end{aligned}
$$

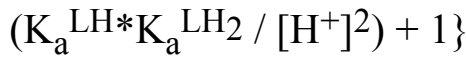

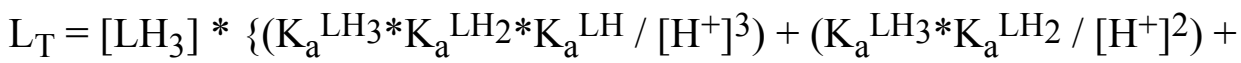

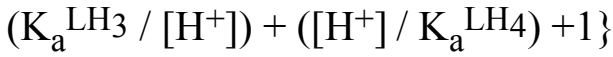

$$
\begin{aligned}
& \mathrm{L}_{\mathrm{T}}=\left[\mathrm{LH}_{4}\right] *\left\{\left(\mathrm{~K}_{\mathrm{a}}^{\mathrm{LH}} 4 * \mathrm{~K}_{\mathrm{a}} \mathrm{LH}_{3} * \mathrm{~K}_{\mathrm{a}}{ }^{\mathrm{LH}}{ }_{2} * \mathrm{~K}_{\mathrm{a}} \mathrm{LH} /\left[\mathrm{H}^{+}\right]^{4}\right)+\left(\mathrm{K}_{\mathrm{a}} \mathrm{LH}_{4} * \mathrm{~K}_{\mathrm{a}} \mathrm{LH}_{3} * \mathrm{~K}_{\mathrm{a}} \mathrm{LH}_{2} /\left[\mathrm{H}^{+}\right]^{3}\right)\right. \\
& \left.+\left(\mathrm{K}_{\mathrm{a}} \mathrm{LH}_{3} * \mathrm{~K}_{\mathrm{a}} \mathrm{LH}_{4} /\left[\mathrm{H}^{+}\right]^{2}\right)+\left(\mathrm{K}_{\mathrm{a}} \mathrm{LH}_{4} /\left[\mathrm{H}^{+}\right]\right)+1\right\} \\
& \mathrm{ML}_{\mathrm{T}}=[\mathrm{ML}] *\left\{\left(\left[\mathrm{H}^{+}\right]^{4} / \mathrm{K}_{\mathrm{a}} \mathrm{MLH}_{4} * \mathrm{~K}_{\mathrm{a}} \mathrm{MLH}_{3} * \mathrm{~K}_{\mathrm{a}} \mathrm{MLH}_{2} * \mathrm{~K}_{\mathrm{a}} \mathrm{MLH}\right)+\right. \\
& \left(\left[\mathrm{H}^{+}\right]^{3} / \mathrm{K}_{\mathrm{a}} \mathrm{MLH}_{3} * \mathrm{~K}_{\mathrm{a}} \mathrm{MLH}_{2} * \mathrm{~K}_{\mathrm{a}} \mathrm{MLH}\right)+\left(\left[\mathrm{H}^{+}\right]^{2} / \mathrm{K}_{\mathrm{a}} \mathrm{MLH}_{2} * \mathrm{~K}_{\mathrm{a}} \mathrm{MLH}^{\mathrm{M}}\right)+ \\
& \left.\left(\left[\mathrm{H}^{+}\right] / \mathrm{K}_{\mathrm{a}}^{\mathrm{MLH}}\right)+1\right\} \\
& \mathrm{ML}_{\mathrm{T}}=[\mathrm{MLH}] *\left\{\left(\left[\mathrm{H}^{+}\right]^{3} / \mathrm{K}_{\mathrm{a}} \mathrm{MLH}_{3} * \mathrm{~K}_{\mathrm{a}} \mathrm{MLH}_{2} * \mathrm{~K}_{\mathrm{a}} \mathrm{MLH}^{\mathrm{M}}\right)+\left(\left[\mathrm{H}^{+}\right]^{2} / \mathrm{K}_{\mathrm{a}} \mathrm{MLH}_{3} * \mathrm{~K}_{\mathrm{a}} \mathrm{MLH}_{2}\right)\right. \\
& \left.+\left(\left[\mathrm{H}^{+}\right] / \mathrm{K}_{\mathrm{a}} \mathrm{MLH}_{3}\right)+\left(\mathrm{K}_{\mathrm{a}} \mathrm{MLH}_{4} /\left[\mathrm{H}^{+}\right]\right)+1\right\} \\
& \mathrm{ML}_{\mathrm{T}}=\left[\mathrm{MLH}_{2}\right] *\left\{\left(\left[\mathrm{H}^{+}\right]^{2} / \mathrm{K}_{\mathrm{a}} \mathrm{MLH}_{3} * \mathrm{~K}_{\mathrm{a}} \mathrm{MLH}_{4}\right)+\left(\left[\mathrm{H}^{+}\right] / \mathrm{K}_{\mathrm{a}} \mathrm{MLH}_{3}\right)+\left(\mathrm{K}_{\mathrm{a}} \mathrm{MLH}_{2} /\left[\mathrm{H}^{+}\right]\right)\right. \\
& \left.+\left(\mathrm{K}_{\mathrm{a}} \mathrm{MLH} * \mathrm{~K}_{\mathrm{a}} \mathrm{MLH}_{2} /\left[\mathrm{H}^{+}\right]^{2}\right)+1\right\} \\
& \mathrm{ML}_{\mathrm{T}}=\left[\mathrm{MLH}_{3}\right] *\left\{\left(\mathrm{~K}_{\mathrm{a}} \mathrm{MLH}_{3} * \mathrm{~K}_{\mathrm{a}} \mathrm{MLH}_{2} * \mathrm{~K}_{\mathrm{a}} \mathrm{MLH} /\left[\mathrm{H}^{+}\right]^{3}\right)+\left(\mathrm{K}_{\mathrm{a}} \mathrm{MLH}_{3} * \mathrm{~K}_{\mathrm{a}} \mathrm{MLH}_{2} /\left[\mathrm{H}^{+}\right]^{2}\right)\right. \\
& \left.+\left(\mathrm{K}_{\mathrm{a}} \mathrm{MLH}_{3} /\left[\mathrm{H}^{+}\right]\right)+\left(\left[\mathrm{H}^{+}\right] / \mathrm{K}_{\mathrm{a}} \mathrm{MLH}_{4}\right)+1\right\} \\
& \mathrm{ML}_{\mathrm{T}}=\left[\mathrm{MLH}_{4}\right] *\left\{\left(\mathrm{~K}_{\mathrm{a}} \mathrm{MLH}_{4} * \mathrm{~K}_{\mathrm{a}} \mathrm{MLH}_{3} * \mathrm{~K}_{\mathrm{a}} \mathrm{MLH}_{2} * \mathrm{~K}_{\mathrm{a}} \mathrm{MLH} /\left[\mathrm{H}^{+}\right]^{4}\right)+\right. \\
& \left(\mathrm{K}_{\mathrm{a}} \mathrm{MLH}_{4} * \mathrm{~K}_{\mathrm{a}} \mathrm{MLH}_{3} * \mathrm{~K}_{\mathrm{a}} \mathrm{MLH}_{2} /\left[\mathrm{H}^{+}\right]^{3}\right)+\left(\mathrm{K}_{\mathrm{a}} \mathrm{MLH}_{3} * \mathrm{~K}_{\mathrm{a}} \mathrm{MLH}_{4} /\left[\mathrm{H}^{+}\right]^{2}\right)+ \\
& \left.\left(\mathrm{K}_{\mathrm{a}} \mathrm{MLH}_{4} /\left[\mathrm{H}^{+}\right]\right)+1\right\}
\end{aligned}
$$


Plugging equation I.37 into I.13 gives:

$$
\begin{aligned}
& { }_{-\mathrm{MLH}_{4}=\left[\mathrm{H}^{+}\right]^{4} /}{ }_{-\mathrm{ML}} \\
& \text { where, } \left.{ }_{-\mathrm{ML}}=\left[\mathrm{H}^{+}\right]^{4}+\mathrm{H}^{+}\right]^{3 *} \mathrm{~K}_{\mathrm{a}} \mathrm{MLH}_{4}+\left[\mathrm{H}^{+}\right]^{2 *} \mathrm{~K}_{\mathrm{a}} \mathrm{MLH}_{4} * \mathrm{~K}_{\mathrm{a}} \mathrm{MLH}_{3}+ \\
& {\left[\mathrm{H}^{+}\right]^{*} \mathrm{~K}_{\mathrm{a}} \mathrm{MLH}_{4} * \mathrm{~K}_{\mathrm{a}} \mathrm{MLH}_{3} * \mathrm{~K}_{\mathrm{a}} \mathrm{MLH}_{2}+\mathrm{K}_{\mathrm{a}} \mathrm{MLH}_{4} * \mathrm{~K}_{\mathrm{a}} \mathrm{MLH}_{3} * \mathrm{~K}_{\mathrm{a}} \mathrm{MLH}_{2} * \mathrm{~K}_{\mathrm{a}} \mathrm{MLH}}
\end{aligned}
$$

Plugging equation I.36 into I.14 gives:

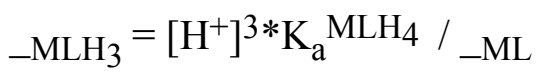

Plugging equation I.35 into I.15 gives:

$$
{ }_{-} \mathrm{MLH}_{2}=\left[\mathrm{H}^{+}\right]^{2 *} \mathrm{~K}_{\mathrm{a}} \mathrm{MLH}_{4} * \mathrm{~K}_{\mathrm{a}} \mathrm{MLH}_{3} /{ }_{-} \mathrm{ML}
$$

Plugging equation I.34 into I.16 gives:

$$
{ }_{-} \mathrm{MLH}=\left[\mathrm{H}^{+}\right] * \mathrm{~K}_{\mathrm{a}} \mathrm{MLH}_{4} * \mathrm{~K}_{\mathrm{a}} \mathrm{MLH}_{3} * \mathrm{~K}_{\mathrm{a}} \mathrm{MLH}_{2} /{ }_{-} \mathrm{ML}
$$

Plugging equation I.33 into I.17 gives:

$$
{ }_{-} \mathrm{ML}=\mathrm{K}_{\mathrm{a}} \mathrm{MLH}_{4} * \mathrm{~K}_{\mathrm{a}} \mathrm{MLH}_{3} * \mathrm{~K}_{\mathrm{a}} \mathrm{MLH}_{2} * \mathrm{~K}_{\mathrm{a}} \mathrm{MLH} /{ }_{-} \mathrm{ML}
$$

Plugging equation I.32 into I.18 gives:

$$
{ }_{-} \mathrm{LH}_{4}=\left[\mathrm{H}^{+}\right]^{4} /{ }_{-}
$$

where, ${ }_{\mathrm{L}}=\left[\mathrm{H}^{+}\right]^{4}+\left[\mathrm{H}^{+}\right]^{3 *} \mathrm{~K}_{\mathrm{a}}{ }^{\mathrm{LH}} 4+\left[\mathrm{H}^{+}\right]^{2 *} \mathrm{~K}_{\mathrm{a}}{ }^{\mathrm{LH}_{4}} * \mathrm{~K}_{\mathrm{a}} \mathrm{LH}_{3}+$ $\left[\mathrm{H}^{+}\right] * \mathrm{~K}_{\mathrm{a}} \mathrm{LH}_{4} * \mathrm{~K}_{\mathrm{a}}{ }^{\mathrm{LH}} 3 * \mathrm{~K}_{\mathrm{a}}{ }^{\mathrm{LH}} 2+\mathrm{K}_{\mathrm{a}}{ }^{\mathrm{LH}}{ }_{4} * \mathrm{~K}_{\mathrm{a}}{ }^{\mathrm{LH}} \mathrm{H}_{3} * \mathrm{~K}_{\mathrm{a}}{ }^{\mathrm{LH}} \mathrm{H}_{2} * \mathrm{~K}_{\mathrm{a}} \mathrm{LH}$

Plugging equation I.31 into I.19 gives:

${ }_{-} \mathrm{LH}_{3}=\left[\mathrm{H}^{+}\right]^{3 *} \mathrm{~K}_{\mathrm{a}} \mathrm{LH}_{4} /_{-} \mathrm{L}$

Plugging equation I.30 into I.20 gives:

$$
{ }_{-} \mathrm{LH}_{2}=\left[\mathrm{H}^{+}\right]^{2 *} \mathrm{~K}_{\mathrm{a}} \mathrm{LH}_{4} * \mathrm{~K}_{\mathrm{a}} \mathrm{LH}_{3} /{ }_{-} \mathrm{L}
$$

Plugging equation I.29 into I.21 gives:

$$
{ }_{-} \mathrm{LH}=\left[\mathrm{H}^{+}\right] * \mathrm{~K}_{\mathrm{a}} \mathrm{LH}_{4} * \mathrm{~K}_{\mathrm{a}} \mathrm{LH}_{3} * \mathrm{~K}_{\mathrm{a}}{ }^{\mathrm{LH}}{ }_{2} /{ }_{-} \mathrm{L}
$$

Plugging equation I.28 into I.22 gives: 
${ }_{-} \mathrm{L}=\mathrm{K}_{\mathrm{a}}^{\mathrm{LH}}{ }_{4} * \mathrm{~K}_{\mathrm{a}} \mathrm{LH}_{3} * \mathrm{~K}_{\mathrm{a}}^{\mathrm{LH}_{2}} * \mathrm{~K}_{\mathrm{a}}^{\mathrm{LH} /}{ }_{-} \mathrm{L}$

An expression for the overall conditional formation constant may be written as:

$$
\mathbf{K}_{\mathbf{f}}{ }^{\prime}=\mathrm{K}_{\mathrm{f}}{ }^{\prime} \mathrm{MLH}_{4}+\mathrm{K}_{\mathrm{f}}{ }^{\prime} \mathrm{MLH}_{3}+\mathrm{K}_{\mathrm{f}}{ }^{{ }^{M} \mathrm{MLH}_{2}}+\mathrm{K}_{\mathrm{f}}{ }^{\prime} \mathrm{MLH}+\mathrm{K}_{\mathrm{f}}{ }^{\prime} \mathrm{ML}
$$

Substituting I.23-I.27 into I.48 yields the final equation used to fit the proton dependence of the conditional formation constant, where the various _ terms and formation constants, $\mathrm{K}_{\mathrm{f}}$, are defined above.

$$
\begin{aligned}
\mathbf{K}_{\mathbf{f}}{ }^{\prime}= & \left(\mathrm{LH}_{4} * \mathrm{~K}_{\mathrm{f}}^{\mathrm{MLH}} 4 / \mathrm{MLH}_{4}\right)+\left(\mathrm{LLH}_{3} * \mathrm{~K}_{\mathrm{f}} \mathrm{MLH}_{3} / \mathrm{MLH}_{3}\right)+\left(\mathrm{LH}_{2} * \mathrm{~K}_{\mathrm{f}} \mathrm{MLH}_{2} / \mathrm{MLH}_{2}\right) \\
& +\left(\mathrm{LLH}^{*} \mathrm{~K}_{\mathrm{f}} \mathrm{MLH} /{ }_{-\mathrm{MLH}}\right)+\left(\mathrm{L}^{*} \mathrm{~K}_{\mathrm{f}} \mathrm{ML} / \mathrm{ML}\right)
\end{aligned}
$$

A simplification of the above equation may be made if one considers that it is found that a $\mathrm{pH}$ titration of ML reveals two protonation events, a one proton event at $\mathrm{K}_{\mathrm{a}} \mathrm{MLH}$ and a three proton cooperative event at $\mathrm{K}_{\mathrm{a}} \mathrm{MLH}_{4}$.

More fundamentally, this means that

$$
\begin{aligned}
& \mathrm{ML}_{\mathrm{T}}=[\mathrm{ML}]+[\mathrm{MLH}]+\left[\mathrm{MLH}_{4}\right] \\
& \mathrm{L}_{\mathrm{T}}=[\mathrm{L}]+[\mathrm{LH}]+\left[\mathrm{LH}_{4}\right]
\end{aligned}
$$

With this in mind, I.49 simplifies to:

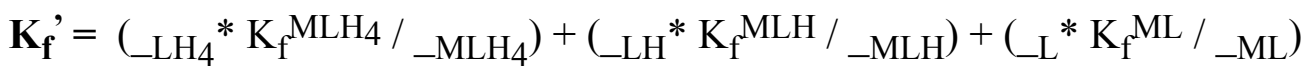

$$
\begin{aligned}
& \text { where } \_\mathrm{LH}_{4}=\left[\mathrm{H}^{+}\right]^{4} / \text { Lcoop } \\
& \text { _LH }=\left[\mathrm{H}^{+}\right]^{*}\left(\mathrm{~K}_{\mathrm{a}} \mathrm{LH}_{4}\right)^{3 /}{ }_{\text {LLcoop }} \\
& -\mathrm{L} \quad=\mathrm{K}_{\mathrm{a}}^{\mathrm{LH} *}\left(\mathrm{~K}_{\mathrm{a}}^{\mathrm{LH}} 4\right)^{3} /{ }_{-} \text {Lcoop } \\
& -\mathrm{MLH}_{4}=\left[\mathrm{H}^{+}\right]^{4} / \text { MLcoop } \\
& \_\mathrm{MLH}=\left[\mathrm{H}^{+}\right]^{*}\left(\mathrm{~K}_{\mathrm{a}} \mathrm{MLH}_{4}\right)^{3} /{ }_{-} \text {MLcoop } \\
& -\mathrm{ML}=\mathrm{K}_{\mathrm{a}} \mathrm{MLH} *\left(\mathrm{~K}_{\mathrm{a}} \mathrm{MLH}_{4}\right)^{3 /} \_ \text {MLcoop } \\
& { }_{-} \text {Lcoop }=\left[\mathrm{H}^{+}\right]^{4}+\left[\mathrm{H}^{+}\right]^{*}\left(\mathrm{~K}_{\mathrm{a}} \mathrm{LH}_{4}\right)^{3}+\mathrm{K}_{\mathrm{a}}^{\mathrm{LH} *}\left(\mathrm{~K}_{\mathrm{a}} \mathrm{LH}_{4}\right)^{3} \\
& - \text { MLcoop }=\left[\mathrm{H}^{+}\right]^{4}+\left[\mathrm{H}^{+}\right]^{*}\left(\mathrm{~K}_{\mathrm{a}} \mathrm{MLH}_{4}\right)^{3}+\mathrm{K}_{\mathrm{a}} \mathrm{MLH} *\left(\mathrm{~K}_{\mathrm{a}} \mathrm{MLH}_{4}\right)^{3}
\end{aligned}
$$

The final equation used to fit the data, I.52, is put in terms of $\mathrm{pH}$ and $\mathrm{pKa}$ 's. Additionally, the following substitutions, which were derived from the thermodynamic scheme in Figure 1, were made: 


$$
\begin{aligned}
& \mathrm{K}_{\mathrm{f}} \mathrm{MLH}=\left(\mathrm{K}_{\mathrm{a}}^{\mathrm{LH}} / \mathrm{K}_{\mathrm{a}} \mathrm{MLH}\right) * \mathrm{~K}_{\mathrm{f}} \mathrm{ML} \\
& \mathrm{K}_{\mathrm{f}} \mathrm{MLH}_{4}=\left(\mathrm{K}_{\mathrm{a}}^{\mathrm{LH}} / \mathrm{K}_{\mathrm{a}}^{\mathrm{MLH}}\right) *\left(\left(\mathrm{~K}_{\mathrm{a}} \mathrm{LH}_{4}\right)^{3} /\left(\mathrm{K}_{\mathrm{a}} \mathrm{MLH}_{4}\right)^{3}\right) * \mathrm{~K}_{\mathrm{f}} \mathrm{ML}
\end{aligned}
$$

The resulting equation that is used to fit the conditional formation constants as a function of $\mathrm{pH}$ is:

$$
\begin{aligned}
& \mathbf{K}_{\mathbf{f}}{ }^{\prime}=\left\{\left(C_{L_{4}} *\left(10\left(-\mathrm{pK}_{\mathrm{a}} \mathrm{LH}_{+} \mathrm{pK}_{\mathrm{a}} \mathrm{MLH}\right) *\left(\left(10\left(-\mathrm{pK}_{\mathrm{a}} \mathrm{LH}_{4} * 3+\mathrm{pK}_{\mathrm{a}} \mathrm{MLH}_{4} * 3\right)\right) * \mathrm{~K}_{\mathrm{f}} \mathrm{ML}\right) /{ }_{-} \mathrm{MLH}_{4}\right)+\right.\right. \\
& \left.\left(\left(\mathrm{LH}^{*} *\left(10\left(-\mathrm{pK}_{\mathrm{a}} \mathrm{LH}_{+\mathrm{pK}} \mathrm{MLH}\right)\right) * \mathrm{~K}_{\mathrm{f}} \mathrm{ML}\right) /{ }_{\mathrm{MLH}}\right)+\left({ }_{-} * \mathrm{~K}_{\mathrm{f}} \mathrm{ML} /{ }_{\mathrm{ML}}\right)\right\} \\
& \text { where }{ }_{-} \mathrm{LH}_{4}=10(-4 * \mathrm{pH}) / \_ \text {Lcoop } \\
& { }_{-} \mathrm{LH}=10\left(-\mathrm{pH}-3 * \mathrm{pK}_{\mathrm{a}} \mathrm{LH}\right) / \_ \text {Lcoop } \\
& { }_{-} \mathrm{L}=10\left(-\mathrm{pK}_{\mathrm{a}} \mathrm{LH}_{4} * 3-\mathrm{pK}_{\mathrm{a}} \mathrm{LH}\right) /{ }_{-} \mathrm{Lcoop} \\
& { }_{-} \mathrm{Lcoop}=10(-4 * \mathrm{pH})+10\left(-\mathrm{pH}-\mathrm{pK}_{\mathrm{a}} \mathrm{LH}_{4} * 3\right)+10\left(-\mathrm{pK}_{\mathrm{a}} \mathrm{LH}_{4} * 3-\mathrm{pK}_{\mathrm{a}} \mathrm{LH}\right) \\
& { }_{-} \mathrm{MLH}_{4}=10(-4 * \mathrm{pH}) /{ }_{-} \mathrm{MLcoop} \\
& { }_{-} \mathrm{MLH}=10\left(-\mathrm{pH}-3 * \mathrm{pK}_{\mathrm{a}} \mathrm{MLH}_{4}\right) /{ }_{-} \mathrm{MLcoop} \\
& { }_{-} \mathrm{ML}=10\left(-\mathrm{pK}_{\mathrm{a}} \mathrm{MLH}_{4} * 3-\mathrm{pK}_{\mathrm{a}} \mathrm{MLH}\right) /{ }_{-\mathrm{MLcoop}} \\
& { }_{-\mathrm{MLcoop}}=10(-4 * \mathrm{pH})+10\left(-\mathrm{pH}-\mathrm{pK}_{\mathrm{a}} \mathrm{MLH}_{4} * 3\right)+10\left(-\mathrm{pK}_{\mathrm{a}} \mathrm{MLH}_{4} * 3-\mathrm{pK}_{\mathrm{a}} \mathrm{MLH}\right)
\end{aligned}
$$

\section{Fitting ML pH Titrations}

A general expression for the change in total signal, $\mathrm{S}_{\mathrm{T}}$, as a function of $\mathrm{pH}$ for the metal substituted ferredoxin maquettes may be written as follows:

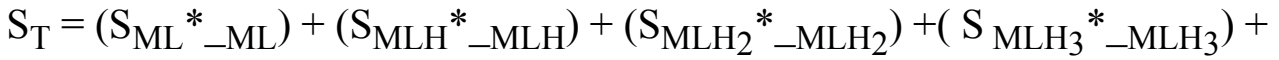

$$
\begin{aligned}
& \left(\mathrm{S}_{\mathrm{MLH}_{4}}{ }^{*}-\mathrm{MLH}_{4}\right)
\end{aligned}
$$

Where $\mathrm{S}_{\mathrm{ML}(\mathrm{H})_{\mathrm{X}}}$ is the intrinsic signal of $\mathrm{ML}(\mathrm{H})_{\mathrm{X}}$ and ${ }_{-M L}(\mathrm{H})_{\mathrm{X}}$ is the fraction of $\mathrm{ML}(\mathrm{H})_{\mathrm{X}}$ present over $\mathrm{ML}_{\mathrm{T}}$.

In the case of the $\mathrm{Fe} / \mathrm{Co} / \mathrm{Zn}$ Ferredoxin Maquettes, the $\mathrm{pH}$ titration is best fit to the following model:

$$
\mathrm{S}_{\mathrm{T}}=\left(\mathrm{S}_{\mathrm{ML}}{ }^{*}{ }_{-\mathrm{ML}}\right)+\left(\mathrm{S}_{\mathrm{MLH}}{ }^{*}{ }_{-} \mathrm{MLH}\right)+\left(\mathrm{S}_{\left.\mathrm{MLH}_{4}{ }^{*}{ }_{-\mathrm{MLH}}\right)}\right)
$$

where ${ }_{-\mathrm{ML}},{ }_{-\mathrm{MLH}}$, and ${ }_{-\mathrm{MLH}}$ are defined in equations I.56-I.58, I.60.

The actual equation used to fit the data is put in terms of $\mathrm{pH}$ and $\mathrm{pKa}$ 's, giving the final expression below. 


$$
\begin{aligned}
& \mathrm{S}_{\mathrm{T}}=\left(\mathrm{S}_{\mathrm{ML}} *\left(\_\mathrm{ML}\right)\right)+\left(\mathrm{S}_{\mathrm{MLH}} *\left(\_\mathrm{MLH}\right)\right)+\left(\mathrm{S}_{\mathrm{MLH} 4} *\left(\_\mathrm{MLH} 4\right)\right) \\
& -\mathrm{MLH}_{4}=10^{(-4 * \mathrm{pH})} /{ }_{-\mathrm{MLcoop}} \\
& -\mathrm{MLH}=10\left(-\mathrm{pH}-3 * \mathrm{pK}_{\mathrm{a}} \mathrm{MLH}_{4}\right) / \_ \text {MLcoop } \\
& \text { _ML }=10\left(-\mathrm{pK}_{\mathrm{a}} \mathrm{MLH}_{4} * 3-\mathrm{pK}_{\mathrm{a}} \mathrm{MLH}\right) / \_ \text {MLcoop } \\
& - \text { MLcoop }=10^{(-4 * \mathrm{pH})}+10\left(-\mathrm{pH}-\mathrm{pK}_{\mathrm{a}} \mathrm{MLH}_{4} * 3\right)+10\left(-\mathrm{pK}_{\mathrm{a}} \mathrm{MLH}_{4} * 3 \mathrm{pK}_{\mathrm{a}} \mathrm{MLH}\right)
\end{aligned}
$$

The above model is one in which there are two protonation events, a one proton event at $\mathrm{K}_{\mathrm{a}}{ }^{\mathrm{MLH}}$ and a three proton cooperative event at $\mathrm{K}_{\mathrm{a}} \mathrm{MLH}_{4}$.

Thus, $\mathrm{K}_{\mathrm{a}} \mathrm{MLH}_{4}=\mathrm{K}_{\mathrm{a}} \mathrm{MLH}_{3}=\mathrm{K}_{\mathrm{a}} \mathrm{MLH}_{2}$.

\section{1:1 Binding Fdm Maquettes (Fluorescence)}

$$
\mathrm{K}_{\mathrm{d}}=[\mathrm{M}] *[\mathrm{~L}] /[\mathrm{ML}]
$$

where, $\mathrm{K}_{\mathrm{d}}$ is the equilibrium dissociation constant, $[\mathrm{M}]$ is the concentration of free metal, [L] is the concentration of free ligand, and [ML] is the concentration of a 1:1 Metal-Ligand Complex.

Consideration of mass balance gives the following expressions:

$$
\begin{aligned}
& \mathrm{L}_{\mathrm{T}}=[\mathrm{ML}]+[\mathrm{L}] \\
& \mathrm{M}_{\mathrm{T}}=[\mathrm{ML}]+[\mathrm{M}]
\end{aligned}
$$

Where $\mathrm{L}_{\mathrm{T}}$ and $\mathrm{M}_{\mathrm{T}}$ are total concentrations of all forms of ligand and metal in solution, respectively.

Substitution of (III.2) and (III.3) into (III.1) results in the following expression,

$$
[\mathrm{ML}]^{2}+-\left(\mathrm{M}_{\mathrm{T}}+\mathrm{L}_{\mathrm{T}}+\mathrm{K}_{\mathrm{d}}\right) *[\mathrm{ML}]+\left(\mathrm{M}_{\mathrm{T}} * \mathrm{~L}_{\mathrm{T}}\right)=0
$$

Solving the quadratic equation leads to the following expression:

$$
[\mathrm{ML}]=\left\{\left(\mathrm{M}_{\mathrm{T}}+\mathrm{L}_{\mathrm{T}}+\mathrm{K}_{\mathrm{d}}\right)-\left\{\left(\mathrm{M}_{\mathrm{T}}+\mathrm{L}_{\mathrm{T}}+\mathrm{K}_{\mathrm{d}}\right)^{2}-\left(4 * \mathrm{M}_{\mathrm{T}} \mathrm{L}_{\mathrm{T}}\right)\right\}^{.5}\right\} / 2
$$

The total fluorescence intensity, F, is governed by the sum of the fluorescence intensities of L and ML, where " $a$ " and " $b$ " are constants proportional to the fluorescence quantum yields of $\mathrm{L}$ and $\mathrm{ML}$, respectively.

$$
\mathrm{F}=\mathrm{a}^{*}[\mathrm{~L}]+\mathrm{b}^{*}[\mathrm{ML}]
$$


The initial fluorescence, $\mathrm{F}_{\mathrm{o}}$, is governed solely by the ligand, $\mathrm{L}$. The final limiting fluorescence, $\mathrm{F}_{\mathrm{lim}}$, is governed solely by the metal-ligand complex, ML. Thus, $F_{o}=F_{L}$, where $F_{L}$ is the intrinsic fluorescence of $\mathrm{L}$, and $F_{\text {lim }}=$ $F_{M L}$, where $F_{M L}$ is the intrinsic fluorescence of ML.

$\mathrm{F}_{\mathrm{o}}=\mathrm{a}^{*} \mathrm{~L}_{\mathrm{T}}$
$\mathrm{F}_{\lim }=\mathrm{b}^{*} \mathrm{~L}_{\mathrm{T}}$

Solving (III.7) and (III.8) for "a" and "b", and plugging into (III.6) gives:

$\mathrm{F}=\left(\left([\mathrm{L}]^{*} \mathrm{~F}_{\mathrm{o}}\right) /\left[\mathrm{L}_{\mathrm{T}}\right]\right)+\left(\left([\mathrm{ML}]^{*} \mathrm{~F}_{\text {lim }}\right) /\left[\mathrm{L}_{\mathrm{T}}\right]\right)$

Expressing "[L]" as " $\mathrm{L}_{\mathrm{T}}-$ [ML]" (III.2), and further simplifying (III.9) leads to:

$$
\mathrm{F}=\mathrm{F}_{\mathrm{o}}+\left\{[\mathrm{ML}] *\left(\mathrm{~F}_{\text {lim }}-\mathrm{F}_{\mathrm{o}}\right) / \mathrm{L}_{\mathrm{T}}\right\}
$$

Substitution of III.5 into [ML] gives:

$$
\begin{aligned}
\mathrm{F}= & \mathrm{F}_{\mathrm{o}}+\left\{\left(\mathrm{F}_{\lim }-\mathrm{F}_{\mathrm{o}}\right) /\left(2 * \mathrm{~L}_{\mathrm{T}}\right)\right\} * \\
& \left\{\left(\mathrm{M}_{\mathrm{T}}+\mathrm{L}_{\mathrm{T}}+\mathrm{K}_{\mathrm{d}}\right)-\left\{\left(\mathrm{M}_{\mathrm{T}}+\mathrm{L}_{\mathrm{T}}+\mathrm{K}_{\mathrm{d}}\right)^{2}-\left(4 * \mathrm{M}_{\mathrm{T}} \mathrm{L}_{\mathrm{T}}\right)\right\}^{.5}\right\}
\end{aligned}
$$

The number of equivalents of metal added relative to peptide, the independent variable, $\mathrm{x}$, is related to $\mathrm{M}_{\mathrm{T}}$ according to:

$$
\mathrm{M}_{\mathrm{T}} / \mathrm{L}_{\mathrm{T}}=\mathrm{x} \rightarrow \quad \mathrm{M}_{\mathrm{T}}=\mathrm{L}_{\mathrm{T}} * \mathrm{x}
$$

Substitution of (III.12) into (III.11) gives the final expression used to fit the 1:1 binding isotherm:

$$
\begin{aligned}
\mathrm{F}= & \mathrm{F}_{\mathrm{o}}+\left\{\left\{\left(\mathrm{F}_{\lim }-\mathrm{F}_{\mathrm{o}}\right) /\left(2^{*} \mathrm{~L}_{\mathrm{T}}\right)\right\} *\right. \\
& \left.\left\{\left(\mathrm{x}^{*} \mathrm{~L}_{\mathrm{T}}+\mathrm{L}_{\mathrm{T}}+\mathrm{K}_{\mathrm{d}}\right)-\left\{\left(\mathrm{x}^{*} \mathrm{~L}_{\mathrm{T}}+\mathrm{L}_{\mathrm{T}}+\mathrm{K}_{\mathrm{d}}\right)^{2}-\left(4 * \mathrm{x} *\left(\mathrm{~L}_{\mathrm{T}}\right)^{2}\right)\right\}^{.5}\right\}\right\}
\end{aligned}
$$




\section{Determining Competition Constants between $\mathrm{Fe} / \mathrm{Co} / \mathrm{Zn}$ substituted $\mathrm{Fdm}$ Maquettes (Fluorescence)}

Consider the following equilibria, where $\mathrm{M}_{\mathrm{A}}$ is a metal displaced by another metal, $\mathrm{M}_{\mathrm{B}}$.

$\mathrm{M}_{\mathrm{A}} \mathrm{L}+\mathrm{M}_{\mathrm{B}} \rightleftharpoons \mathrm{M}_{\mathrm{B}} \mathrm{L}+\mathrm{M}_{\mathrm{A}}$

The equilibrium competition constant, $\mathrm{K}_{\text {comp }}{ }^{\mathrm{AB}}$, may be defined as:

$\mathrm{K}_{\text {comp }} \mathrm{A} / \mathrm{B}=\left[\mathrm{M}_{\mathrm{B}} \mathrm{L}\right]^{*}\left[\mathrm{M}_{\mathrm{A}}\right] /\left[\mathrm{M}_{\mathrm{A}} \mathrm{L}\right]^{*}\left[\mathrm{M}_{\mathrm{B}}\right]$

Consideration of mass balance gives the following expressions:

$\mathrm{L}_{\mathrm{T}}=\left[\mathrm{M}_{\mathrm{B}} \mathrm{L}\right]+\left[\mathrm{M}_{\mathrm{A}} \mathrm{L}\right]$

$\mathrm{M}_{\mathrm{AT}}=\left[\mathrm{M}_{\mathrm{A}} \mathrm{L}\right]+\left[\mathrm{M}_{\mathrm{A}}\right]$

$\mathrm{M}_{\mathrm{BT}}=\left[\mathrm{M}_{\mathrm{B}} \mathrm{L}\right]+\left[\mathrm{M}_{\mathrm{B}}\right]$

Where $\mathrm{L}_{\mathrm{T}}, \mathrm{M}_{\mathrm{AT}}$, and $\mathrm{M}_{\mathrm{BT}}$ are the total concentrations of all forms of ligand metal A, and metal B in solution, respectively.

Substitution of (IV.3)-(IV.5) into (IV.2), and algebraic rearrangement results in the following expression:

$\mathrm{A} *\left[\mathrm{M}_{\mathrm{B}} \mathrm{L}\right]^{2}+\mathrm{B} *\left[\mathrm{M}_{\mathrm{B}} \mathrm{L}\right]-\mathrm{K}_{\mathrm{comp}} \mathrm{A} / \mathrm{B} * \mathrm{M}_{\mathrm{BT}} * \mathrm{~L}_{\mathrm{T}}=0$

Where, $\mathrm{A}=1-\mathrm{K}_{\text {comp }}{ }^{\mathrm{A} / \mathrm{B}}$

$\mathrm{B}=\mathrm{M}_{\mathrm{AT}}-\mathrm{L}_{\mathrm{T}}+\left(\mathrm{K}_{\text {comp }}{ }^{\mathrm{A} / \mathrm{B}}\right)\left(\mathrm{L}_{\mathrm{T}}\right)+\left(\mathrm{K}_{\mathrm{comp}}{ }^{\mathrm{A} / \mathrm{B}}\right)\left(\mathrm{M}_{\mathrm{BT}}\right)$

Solving the quadratic equation leads to the following expression:

$\left[\mathrm{M}_{\mathrm{B}} \mathrm{L}\right]=\left\{-\mathrm{B}+\left\{\mathrm{B}^{2}+\left(4 * \mathrm{~A} * \mathrm{~K}_{\mathrm{comp}} \mathrm{A} / \mathrm{B} * \mathrm{M}_{\mathrm{BT}} * \mathrm{~L}_{\mathrm{T}}\right)\right\}^{.5}\right\} / 2 \mathrm{~A}$

The total fluorescence intensity, $F$, is governed by the sum of the fluorescence intensities of $\mathrm{M}_{\mathrm{A}} \mathrm{L}$ and $\mathrm{M}_{\mathrm{B}} \mathrm{L}$, where "a" and " $\mathrm{b}$ " are constants proportional to the fluorescence quantum yields of $\mathrm{M}_{\mathrm{A}} \mathrm{L}$ and $\mathrm{M}_{\mathrm{B}} \mathrm{L}$, respectively.

$\mathrm{F}=\mathrm{a} *\left[\mathrm{M}_{\mathrm{A}} \mathrm{L}\right]+\mathrm{b} *\left[\mathrm{M}_{\mathrm{B}} \mathrm{L}\right]$

The initial fluorescence, $\mathrm{F}_{\mathrm{O}}$, is governed solely by $\mathrm{M}_{\mathrm{A}} \mathrm{L}$. The final limiting fluorescence, $\mathrm{F}_{\text {lim }}$, is governed solely by $\mathrm{M}_{\mathrm{B}} \mathrm{L}$. 
$\mathrm{F}_{\mathrm{o}}=\mathrm{a}^{*}\left[\mathrm{~L}_{\mathrm{T}}\right]$

$\mathrm{F}_{\text {lim }}=\mathrm{b}^{*}\left[\mathrm{~L}_{\mathrm{T}}\right]$

Solving (IV.9) and (IV.10) for "a" and "b", and plugging into (IV.8) gives:

$\mathrm{F}=\left(\left(\left[\mathrm{M}_{\mathrm{A}} \mathrm{L}\right] * \mathrm{~F}_{\mathrm{o}}\right) /\left[\mathrm{L}_{\mathrm{T}}\right]\right)+\left(\left(\left[\mathrm{M}_{\mathrm{B}} \mathrm{L}\right] * \mathrm{~F}_{\mathrm{lim}}\right) /\left[\mathrm{L}_{\mathrm{T}}\right]\right)$

Expressing " $\left[\mathrm{M}_{\mathrm{A}} \mathrm{L}\right]$ " as " $\mathrm{L}_{\mathrm{T}}-\left[\mathrm{M}_{\mathrm{B}} \mathrm{L}\right]$ " (IV.3), and further simplifying (IV.11) leads to:

$\mathrm{F}=\mathrm{F}_{\mathrm{o}}+\left\{\left[\mathrm{M}_{\mathrm{B}} \mathrm{L}\right]^{*}\left(\mathrm{~F}_{\mathrm{lim}}-\mathrm{F}_{\mathrm{o}}\right) / \mathrm{L}_{\mathrm{T}}\right\}$

Substitution of IV.7 into $\left[\mathrm{M}_{\mathrm{B}} \mathrm{L}\right]$ gives:

$$
\mathrm{F}=\mathrm{F}_{\mathrm{o}}+\left\{\left\{-\mathrm{B}+\left\{\mathrm{B}^{2}+\left(4 * \mathrm{~A} * \mathrm{~K}_{\mathrm{comp}} \mathrm{A} / \mathrm{B} * \mathrm{M}_{\mathrm{BT}} * \mathrm{~L}_{\mathrm{T}}\right)\right\}^{.5}\right\} / 2 \mathrm{~A}^{*} \mathrm{~L}_{\mathrm{T}}\right\} *\left(\mathrm{~F}_{\text {lim }}-\mathrm{F}_{\mathrm{o}}\right)
$$

The number of equivalents of metal $\mathrm{B}$ added relative to peptide, the independent variable, $\mathrm{x}$, is related to $\mathrm{M}_{\mathrm{BT}}$ according to:

$\mathrm{M}_{\mathrm{BT}} / \mathrm{L}_{\mathrm{T}}=\mathrm{x} \rightarrow \mathrm{M}_{\mathrm{BT}}=\mathrm{L}_{\mathrm{T}} * \mathrm{x}$

Substitution of (IV.14) into (IV.13) gives the final expression used to fit the competition equilibrium:

$$
\begin{aligned}
& \mathrm{F}=\mathrm{F}_{\mathrm{o}}+\left\{\left\{-\mathrm{B}+\left\{\mathrm{B}^{2}+\left(4 * \mathrm{~A} * \mathrm{~K}_{\mathrm{comp}} \mathrm{A} / \mathrm{B} * \mathrm{x}^{*} \mathrm{~L}_{\mathrm{T}}^{2}\right)\right\}^{.5}\right\} / 2 \mathrm{~A} * \mathrm{~L}_{\mathrm{T}}\right\} *\left(\mathrm{~F}_{\text {lim }}-\mathrm{F}_{\mathrm{o}}\right) \\
& \mathrm{A}=1-\mathrm{K}_{\mathrm{comp}}{ }^{\mathrm{A} / \mathrm{B}} \\
& \mathrm{B}=\mathrm{M}_{\mathrm{AT}}-\mathrm{L}_{\mathrm{T}}+\left(\mathrm{K}_{\mathrm{comp}} \mathrm{A} / \mathrm{B}\right)\left(\mathrm{L}_{\mathrm{T}}\right)+\left(\mathrm{K}_{\mathrm{comp}} \mathrm{A} / \mathrm{B}\right)\left(\mathrm{x} * \mathrm{~L}_{\mathrm{T}}\right)
\end{aligned}
$$

\section{Determining Competition Constants between $\mathrm{Fe} / \mathrm{Co} / \mathrm{Zn}$ substituted Fdm} Maquettes (Absorbance)

Consider the following equilibria, where $\mathrm{M}_{\mathrm{A}}$ is a metal displaced by another metal, $\mathrm{M}_{\mathrm{B}}$.

$$
\mathrm{M}_{\mathrm{A}} \mathrm{L}+\mathrm{M}_{\mathrm{B}} \rightleftharpoons \mathrm{M}_{\mathrm{B}} \mathrm{L}+\mathrm{M}_{\mathrm{A}}
$$

The equilibrium competition constant, $\mathrm{K}_{\text {comp }}{ }^{\mathrm{A} / \mathrm{B}}$, expressed as an equilibrium formation constant, may be defined as:

$$
\mathrm{K}_{\mathrm{comp}} \mathrm{A} / \mathrm{B}=\left[\mathrm{M}_{\mathrm{B}} \mathrm{L}\right]^{*}\left[\mathrm{M}_{\mathrm{A}}\right] /\left[\mathrm{M}_{\mathrm{A}} \mathrm{L}\right]^{*}\left[\mathrm{M}_{\mathrm{B}}\right]
$$

Consideration of mass balance gives the following expressions: 


$$
\begin{aligned}
& \mathrm{L}_{\mathrm{T}}=\left[\mathrm{M}_{\mathrm{B}} \mathrm{L}\right]+\left[\mathrm{M}_{\mathrm{A}} \mathrm{L}\right] \\
& \mathrm{M}_{\mathrm{AT}}=\left[\mathrm{M}_{\mathrm{A}} \mathrm{L}\right]+\left[\mathrm{M}_{\mathrm{A}}\right] \\
& \mathrm{M}_{\mathrm{BT}}=\left[\mathrm{M}_{\mathrm{B}} \mathrm{L}\right]+\left[\mathrm{M}_{\mathrm{B}}\right]
\end{aligned}
$$

Where $\mathrm{L}_{\mathrm{T}}, \mathrm{M}_{\mathrm{AT}}$, and $\mathrm{M}_{\mathrm{BT}}$ are the total concentrations of all forms of ligand metal A, and metal $\mathrm{B}$ in solution, respectively.

Substitution of (V.3)-(V.5) into (V.2), and algebraic rearrangement results in the following expression:

$$
\mathrm{A}^{*}\left[\mathrm{M}_{\mathrm{B}} \mathrm{L}\right]^{2}+\mathrm{B} *\left[\mathrm{M}_{\mathrm{B}} \mathrm{L}\right]-\mathrm{K}_{\mathrm{comp}}{ }^{\mathrm{A} / \mathrm{B} *} \mathrm{M}_{\mathrm{BT}} * \mathrm{~L}_{\mathrm{T}}=0
$$

$$
\text { Where, } \begin{aligned}
\mathrm{A} & =1-\mathrm{K}_{\text {comp }}{ }^{\mathrm{A} / \mathrm{B}} \\
\mathrm{B} & =\mathrm{M}_{\mathrm{AT}}-\mathrm{L}_{\mathrm{T}}+\left(\mathrm{K}_{\text {comp }}{ }^{\mathrm{A} / \mathrm{B}}\right)\left(\mathrm{L}_{\mathrm{T}}\right)+\left(\mathrm{K}_{\mathrm{comp}}^{\mathrm{A} / \mathrm{B}}\right)\left(\mathrm{M}_{\mathrm{BT}}\right)
\end{aligned}
$$

Solving the quadratic equation leads to the following expression:

$$
\left[\mathrm{M}_{\mathrm{B}} \mathrm{L}\right]=\left\{-\mathrm{B}+\left\{\mathrm{B}^{2}+\left(4 * \mathrm{~A} * \mathrm{~K}_{\text {comp }} \mathrm{A} / \mathrm{B} * \mathrm{M}_{\mathrm{BT}}{ }^{*} \mathrm{~L}_{\mathrm{T}}\right)\right\}^{.5}\right\} / 2 \mathrm{~A}
$$

The total absorbance, Abs, is governed by the sum of an initial absorbance, $A b s_{o}$, and the absorbencies of $\mathrm{M}_{\mathrm{A}} \mathrm{L}$ and $\mathrm{M}_{\mathrm{B}} \mathrm{L}$, where " $\mathrm{E}_{\mathrm{A}} \mathrm{L}$ " and " $\varepsilon_{\mathrm{M}_{\mathrm{B}} \mathrm{L}}$ " are the extinction coefficients of $\mathrm{M}_{\mathrm{A}} \mathrm{L}$ and $\mathrm{M}_{\mathrm{B}} \mathrm{L}$, respectively. "b" is the path length of the cuvette.

$$
\text { Abs }=\operatorname{Abs}_{\mathrm{o}}+\varepsilon_{\mathrm{M}_{\mathrm{A}}} \mathrm{L}^{*} \mathrm{~b}^{*}\left[\mathrm{M}_{\mathrm{A}} \mathrm{L}\right]+\varepsilon_{\mathrm{M}_{\mathrm{B}} \mathrm{L}} * \mathrm{~b} *\left[\mathrm{M}_{\mathrm{B}} \mathrm{L}\right]
$$

Expressing " $\left[\mathrm{M}_{\mathrm{A}} \mathrm{L}\right]$ ” as " $\mathrm{L}_{\mathrm{T}}-\left[\mathrm{M}_{\mathrm{B}} \mathrm{L}\right]$ " (V.3), leads to

$$
\text { Abs }=\operatorname{Abs}_{\mathrm{o}}+\varepsilon_{\mathrm{M}_{\mathrm{A}} \mathrm{L}} * \mathrm{~b}^{*}\left[\mathrm{~L}_{\mathrm{T}}-\left[\mathrm{M}_{\mathrm{B}} \mathrm{L}\right]\right]+\varepsilon_{\mathrm{M}_{\mathrm{B}} \mathrm{L}} * \mathrm{~b}^{*}\left[\mathrm{M}_{\mathrm{B}} \mathrm{L}\right]
$$

Simplification of (V.9) gives (V.10). Substitution of V.7 into [ $\left.\mathrm{M}_{\mathrm{B}} \mathrm{L}\right]$ gives (V.11).

$$
\begin{aligned}
& \text { Abs }=\operatorname{Abs}_{\mathrm{o}}+\left(\varepsilon_{\mathrm{M}_{\mathrm{A}} \mathrm{L}}{ }^{\mathrm{b}} \mathrm{L}_{\mathrm{T}}+\left(\varepsilon_{\mathrm{M}_{\mathrm{B}} \mathrm{L}} * \mathrm{~b}-\varepsilon_{\mathrm{M}_{\mathrm{A}} \mathrm{L}} * \mathrm{~b}\right) *\left[\mathrm{M}_{\mathrm{B}} \mathrm{L}\right]\right) \\
& \text { Abs }=\mathrm{Abs}_{\mathrm{o}}+\left(\varepsilon_{\mathrm{M}_{\mathrm{A}} \mathrm{L}} * \mathrm{~b}^{*} \mathrm{~L}_{\mathrm{T}}+\left(\varepsilon_{\mathrm{M}_{\mathrm{B}} \mathrm{L}}{ }^{* b}-\varepsilon_{\mathrm{M}_{\mathrm{A}} \mathrm{L}}{ }^{*} \mathrm{~b}\right) *\right.
\end{aligned}
$$

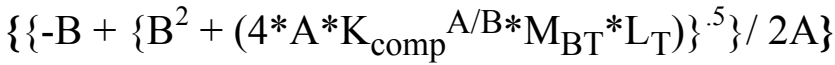

The number of equivalents of metal $\mathrm{B}$ added relative to peptide, the independent variable, $\mathrm{x}$, is related to $\mathrm{M}_{\mathrm{BT}}$ according to: 


$$
\mathrm{M}_{\mathrm{BT}} / \mathrm{L}_{\mathrm{T}}=\mathrm{x} \rightarrow \mathrm{M}_{\mathrm{BT}}=\mathrm{L}_{\mathrm{T}}{ }_{\mathrm{x}}
$$

Substitution of (V.12) into (V.11) gives the final expression used to fit the competition equilibrium:

$$
\begin{aligned}
& \text { Abs }=\text { Abso }+\left(\varepsilon_{M_{A}}{ }^{*} b^{*} L_{T}+\left(\varepsilon_{M_{B}}{ }^{* b}-\varepsilon_{M_{A}}{ }^{* b}\right) *\right. \\
& \left\{\left\{-\mathrm{B}+\left\{\mathrm{B}^{2}+\left(4 * \mathrm{~A} * \mathrm{~K}_{\mathrm{comp}} \mathrm{A} / \mathrm{B} * \mathrm{x}^{*} \mathrm{~L}_{\mathrm{T}}{ }^{2}\right)\right\}{ }^{.5}\right\} / 2 \mathrm{~A}\right\} \\
& \mathrm{A}=1-\mathrm{K}_{\mathrm{comp}} \mathrm{A} / \mathrm{B} \\
& \mathrm{B}=\mathrm{M}_{\mathrm{AT}}-\mathrm{L}_{\mathrm{T}}+\left(\mathrm{K}_{\text {comp }}{ }^{\mathrm{A} / \mathrm{B}}\right)\left(\mathrm{L}_{\mathrm{T}}\right)+\left(\mathrm{K}_{\mathrm{comp}}{ }^{\mathrm{A} / \mathrm{B}}\right)\left(\mathrm{x} * \mathrm{~L}_{\mathrm{T}}\right)
\end{aligned}
$$

\section{References}

A.E Martell and R.M Smith, Critical Stability Constants, Vol. 1 (New York: Plenum Press, 1974) 